\title{
Physiological and Transcriptional Response of Xanthomonas oryzae pv. oryzae to Berberine, an Emerging Chemical Control
}

\author{
Ping Yang, ${ }^{1}$ Fang-Jing Li, ${ }^{1}$ Shi-Wen Huang, ${ }^{1,2}$ Man Luo, ${ }^{1}$ Wei Lin, ${ }^{1}$ Gao-Qing Yuan, ${ }^{1, \dagger}$ and Qi-Qin Li1, \\ ${ }^{1}$ College of Agriculture, Guangxi University, Nanning 530004, People's Republic of China \\ 2 Rice Technology R\&D Center, China National Rice Research Institute, Hangzhou 310006, People's Republic of China \\ Accepted for publication 19 January 2020.
}

ABSTRACT

\begin{abstract}
Berberine, a botanical drug, has great ability to inhibit the growth of Xanthomonas oryzae pv. oryzae. However, the antibacterial mechanism of berberine against $X$. oryzae pv. oryzae remains poorly understood. In this study, we investigated the physiological and transcriptional response of $X$. oryzae pv. oryzae to berberine. When strain X. oryzae pv. oryzae GX13 was treated with berberine $(10 \mu \mathrm{g} / \mathrm{ml})$, the hypersensitive response in tobacco, virulence to rice, pathogen population in the rice xylem, production of extracellular polysaccharide (EPS), and activity of extracellular hydrolases decreased, but the levels of pyruvate and ATP increased. Moreover, biofilm formation was inhibited, and the cell membrane was damaged. Transcriptome sequencing analysis showed downregulated expression of $g s p D, g s p E$, and $g s p F$, involved in the type II secretion system (T2SS); $h r c C, h r c J, h r c N$, and others, involved in the type III secretion system (T3SS); gumB and gumC, associated with EPS; $z a p E, f t s Q$, and zapA, associated with cell division; lpxH, lpxK, $k d t A$, and
\end{abstract}

others, associated with the membrane; and $p y k, p g k$, and $m d h$, encoding pyruvate kinase, phosphoglycerate kinase, and malate dehydrogenase, respectively. Upregulated expression was observed for $п и о A$, пиов, and $n u o H$, encoding the NADH dehydrogenase complex, and $\operatorname{atp} F$, atpC , and $a t p B$, encoding ATP synthase. An adenylate cyclase (CyaA) fusion assay showed that berberine affects type three effector protein secretion via the T3SS and reduces effector translocation in X. oryzae pv. oryzae. It is speculated that the negative growth and virulence phenotypes of berberine-treated $X$. oryzae pv. oryzae GX13 may involve differentially expressed genes associated with cytoarchitecture and energy metabolism, and these effects on primary cell function may further dampen virulence and result in differential expression of T3SS- and T2SS-related genes.

Keywords: berberine, cytoarchitecture, physiology, transcriptome, Xanthomonas oryzae pv. oryzae
Bacterial leaf blight (BLB) of rice caused by Xanthomonas oryzae pv. oryzae is an important rice disease in all rice-growing areas of the world and can reduce yields by $50 \%$. Planting of disease-resistant cultivars is the most economical and efficient means to control this disease, but BLB-resistant rice cultivars are not available in some rice-growing areas (Sakthivel et al. 2017). Moreover, the disease has epidemic, fulminant, and destructive characteristics. As an emergency measure, bactericidal control remains an indispensable means to control BLB. However, only a few bactericides, such as zinc thiazole and thiodiazole copper, are registered in China (Chen et al. 2015), and the development of a new bactericide to manage this disease is desirable.

Phytochemicals have attracted attention in the development of bactericides because of the low toxicity and easy degradability of these compounds. Berberine is a quaternary ammonium salt of isoquinoline alkaloids produced by many plants, such as Coptis spp., Phellodendron amurense, and Mahonia fortunei (Yu and Yang 2005). Berberine has been widely used in medicine because this compound has a wide range of biological activities, such as antibacterial, antiviral, and antioxidant activities, and has synergistic effects with various antibiotics and antitumor drugs (Huang et al. 2018). Berberine also shows potential application prospects

†Corresponding authors: Q.-Q. Li; qqli5806@gxu.edu.cn, and G.-Q. Yuan; ygqtdc@sina.com

Funding: This work was supported by National Natural Science Foundation of China (grant number 31560523)

*The $\boldsymbol{e}$-Xtra logo stands for "electronic extra" and indicates that eight supplementary figures and five supplementary tables are published online.

The author(s) declare no conflict of interest.

(C) 2020 The American Phytopathological Society in agriculture, inhibiting many plant pathogens such as Alternaria brassicicola, Colletotrichum musae, Erysiphe pisi, and Monilinia fructicola (Fu et al. 2017). Berberine was recognized as a promising alternative to chemical fungicides for the management of peach brown rot (Fu et al. 2017). It was found that berberine exhibited strong antibacterial activity against $X$. oryzae pv. oryzae and favorable control effects against bacterial leaf streak of rice (Yuan et al. 2017). A commercial preparation of berberine has been developed to control various plant diseases in China, such as pepper blight, tomato gray mold, cucumber powdery mildew, and angular leaf spot of cucumber (Chen et al. 2012).

Berberine exerts antimicrobial activity by acting on multiple microbial targets. Berberine can damage the cell wall of Actinobacillus pleuropneumoniae and inhibit pyruvate oxidation in the process of sugar metabolism in this bacterium, limiting the uptake of vitamin B6 and nicotinamide and other functions of the bacterium (Kang et al. 2015). Sack and Froehlich (1982) found that berberine could directly inhibit the secretory responses of the heat-labile enterotoxins of Vibrio cholerae and Escherichia coli (Sack and Froehlich 1982). The bacteriostatic mechanism of action of berberine against $E$. coli includes inhibition of DNA replication, RNA transcription, and protein biosynthesis, influencing or inhibiting enzyme activities, destroying the bacterial cell surface structure, and resulting in $\mathrm{Ca}^{2+}$ and $\mathrm{K}^{+}$release from cells (Jin et al. 2011). Therefore, the antibacterial effect of berberine on microorganisms appears to involve changes in cell structure and physiology. However, studies have not yet revealed the overall response of microorganisms to berberine.

Illumina HiSeq-based transcriptomic analysis has been used previously to investigate the effects of bioactive compounds on various microorganisms by identifying the genetic pathways that are altered by the application of a chemical (Liang et al. 2016; Molina-Santiago et al. 2015; Wang et al. 2014). In this study we evaluated the effects of berberine on the growth, virulence, cell 
structure, and physiology of $X$. oryzae pv. oryzae GX13 and analyzed the transcriptomes of $X$. oryzae pv. oryzae GX13 with or without berberine treatment. In addition, the effect of berberine on the type III secretion system (T3SS) of X. oryzae pv. oryzae GX13 was also tested. The results revealed the overall response of $X$. oryzae pv. oryzae to berberine and provide a theoretical basis for further application of berberine.

\section{MATERIALS AND METHODS}

Chemical agents, rice cultivar, assay kits, and culture media. Berberine was obtained from Shanghai Aladdin Bio-Chem Technology Co., Ltd., China. Methanol, chloroform, butanol and other reagents for media preparation were of the highest grade commercially available. The rice cultivar Yusizhan was provided by Guangxi Doctoral Garden Seed Co., Ltd., China. The biochemical reaction assay kit was obtained from Suzhou Comin Biotechnology Co., Ltd., China. DNA polymerase was purchased from Sangon Biotech Co., Ltd., China. A direct cyclic adenosine monophosphate (cAMP) correlation enzyme immunoassay kit was obtained from Abcam, Shanghai, China. The protein assay kit was obtained from Bio-Rad, Beijing, China.

Details about the preparation of culture media, namely nutrient agar (NA) and nutrient broth (NB), lysogeny broth (LB), and the detection of cellulase, protease, and amylase are provided in the relevant references (Chen et al. 2015; Fan et al. 2014). When necessary, antibiotics were used at the following concentrations: rifampicin, $20 \mu \mathrm{g} / \mathrm{ml}$; ampicillin, $50 \mu \mathrm{g} / \mathrm{ml}$; tetracycline, $15 \mu \mathrm{g} / \mathrm{ml}$ for $E$. coli and $5 \mu \mathrm{g} / \mathrm{ml}$ for $X$. oryzae pv. oryzae; and kanamycin, $25 \mu \mathrm{g} / \mathrm{ml}$.

Bacterial strains, growth conditions, and berberine treatment. The strain $X$. oryzae pv. oryzae GX13, which was isolated from infected rice in Nanning, Guangxi, China and confirmed as the pathogen of BLB of rice via Koch's postulates, was preserved at the Plant Pathology Research Institute of Guangxi University, Nanning, China. The strain was stored in $20 \%$ glycerol at $-80^{\circ} \mathrm{C}$ and was initially cultured on NA at $28^{\circ} \mathrm{C}$ for 2 days and then transferred into NB. The NB culture was shaken at $28^{\circ} \mathrm{C}$ with shaking at $130 \mathrm{rpm}$ for $24 \mathrm{~h}$ (during the logarithmic phase) and then diluted to $10^{8} \mathrm{CFU} / \mathrm{ml}$.

Escherichia coli. DH5 $\alpha \mathrm{MCR}$ was purchased from Sangon Biotech Co., Ltd., China and cultured in LB at $37^{\circ} \mathrm{C}$. The E. coli strain containing a plasmid pJAA, which was provided by the lab of State Key Laboratory for Conservation and Utilization of Subtropical Agro-bioresources, Guangxi University, Nanning, China, was cultured in $\mathrm{LB}$ at $37^{\circ} \mathrm{C}$. Berberine was dissolved with methanol (1\% methanol, final concentration) and added to the bacterial suspension to obtain a final berberine concentration. A bacterial suspension containing only $1 \%$ methanol served as the control.

In vitro test for antibacterial activity of berberine against $X$. oryzae pv. oryzae. Strain $X$. oryzae pv. oryzae GX13 was grown in NB medium at $28^{\circ} \mathrm{C}$ with shaking at $130 \mathrm{rpm}$. Cells were harvested at the early logarithmic phase and suspended in an equal volume of sterilized double-distilled $\mathrm{H}_{2} \mathrm{O}$. Then, berberine solutions with final concentrations of $0.5,1,2,4$, and $8 \mu \mathrm{g} /$ $\mathrm{ml}$ (the inhibitory rate is 10 to $90 \%$ ) were mixed with a $10^{7} \mathrm{CFU} / \mathrm{ml}$ suspension of $X$. oryzae pv. oryzae, and a $1 \%$ methanol solution was used as the control. All inoculation broths were grown at $28^{\circ} \mathrm{C}$ with shaking at $130 \mathrm{rpm}$ for $24 \mathrm{~h}$, the optical density at $600 \mathrm{~nm}\left(\mathrm{OD}_{600}\right)$ was measured, and the percentage of bacterial growth inhibition was determined as $(1-A t / A c) \times 100$, where $A c$ and $A t$ were an average of three replicates of the $\mathrm{OD}_{600}$ of the controls and berberine treatment samples, respectively. The half maximal inhibitory concentration ( $\mathrm{IC}_{50}$ ) was calculated via the linear relationship between the probability of inhibition and the logarithmically transformed concentration.

The minimum inhibitory concentration (MIC) and minimum bactericidal concentration (MBC) of berberine against $X$. oryzae $\mathrm{pv}$. oryzae were determined by two broth dilution methods (Woods et al. 2003). The final concentrations of berberine solution were $1.25,2.5,5,10,20,40$, and $80 \mu \mathrm{g} / \mathrm{ml}$. The solutions were mixed with a $10^{7} \mathrm{CFU} / \mathrm{ml}$ suspension of X. oryzae pv. oryzae and cultured for 24 $\mathrm{h}$, and the growth of the pathogen was observed. A 100- $\mu$ l liquid aliquot from each treatment was plated on NA to determine the MIC (the nutrient broth was clarified and the bacteria showed growth on an NA plate within $48 \mathrm{~h}$ ) and MBC (the nutrient broth was clarified and the bacteria could not grow on an NA plate within $96 \mathrm{~h}$ ).

Growth determination assays were performed on NB culture with final berberine concentrations of the $\mathrm{IC}_{50}$ and MIC, then mixed with $10^{7} \mathrm{CFU} / \mathrm{ml}$ and $10^{8} \mathrm{CFU} / \mathrm{ml}$ concentrations of $X$. oryzae $\mathrm{pv}$. oryzae, and a $1 \%$ methanol solution was used as the control. All inoculation broths were cultured for $24 \mathrm{~h}$, and the $\mathrm{OD}_{600}$ was measured every 4 or $8 \mathrm{~h}$ until bacterial growth reached the stationary stage. Each treatment consisted of three replicates.

Virulence assay and $X$. oryzae pv. oryzae population in rice leaves. Virulence assay of $X$. oryzae pv. oryzae after berberine treatment was performed on the rice cultivar Yusizhan via the leaf clipping method (Yang and Bogdanove 2013). The rice was cultivated in 20 -cm-diameter pots (10 plants per pot) in a greenhouse at $30 \pm 3^{\circ} \mathrm{C}$. Strain $\mathrm{GX} 13$ of $X$. oryzae pv. oryzae was treated with berberine $(10 \mu \mathrm{g} / \mathrm{ml})$ and cultured for $24 \mathrm{~h}$ (berberine treatment), and a $1 \%$ methanol solution was used as a control (wildtype [WT] treatment). Inoculations were performed by immersing scissors in freshly prepared bacterial suspensions at a concentration of $10^{8} \mathrm{CFU} / \mathrm{ml}$ and clipping approximately $2 \mathrm{~cm}$ from the tips of fully expanded leaves at the tillering stage. The lesion lengths (i.e., the lengths of the grayish lesions from the inoculated tip to the leading edge) were measured 20 days postinoculation (dpi). Each treatment consisted of three replicates, and each replicate contained $\geq 15$ leaves. A 5 -cm leaf segment from the point of inoculation was cut and measured its width at 3, 5, 7, 9, and $11 \mathrm{dpi}$, respectively. Bacterial cells were recovered from leaf segments, and the $X$. oryzae pv. oryzae population was determined and expressed as $\mathrm{CFU} / \mathrm{cm}^{2}$ rice leaf as described by Laha and Muralidharan (2008). The experiment was repeated three times.

Effect of berberine on BLB lesions assays in greenhouse. Rice plants were cultivated as described above. The pathogen inoculation method was the same as that used for the virulence assay. The concentrations of $0.1,0.25$, and $0.5 \mathrm{~g} /$ liter berberine solution were sprayed on rice leaves at a dosage of $10 \mathrm{ml}$ per plant at $24 \mathrm{~h}$ after $X$. oryzae pv. oryzae inoculation. Plants treated with $1 \%$ methanol served as controls, and bismerthiazol at a concentration of $0.4 \mathrm{~g} / \mathrm{liter}$ was used as the bactericide control. The length of lesions on the clipped leaves was measured at 10 and 15 days after pathogen inoculation, and the inhibition rate of lesion expansion on leaves was calculated as described by Liang et al. (2015). Each treatment consisted of three replicates, and each replicate contained 30 leaves. The biological experiments were performed three times.

$$
\begin{aligned}
& \text { Inhibition rate of lesion expansion on leaves }(\%) \\
& \qquad \begin{array}{r}
=(\text { lesion length of the reference control } \\
- \text { lesion length of the pesticide group }) / \\
\text { lesion length of the reference control } \times 100
\end{array}
\end{aligned}
$$

Virulence factor assays. Effect of berberine on biofilms. A sterile paper pan was submerged in an $X$. oryzae pv. oryzae suspension and incubated for $60 \mathrm{~h}$ at $28^{\circ} \mathrm{C}$. Berberine at the MIC was mixed with $X$. oryzae pv. oryzae suspension and incubated for $12 \mathrm{~h}$ at $28^{\circ} \mathrm{C}$, and a $1 \%$ methanol solution was used as the control. The paper pan was transferred to a sterile Eppendorf tube after washing three times with phosphate-buffered saline (PBS) and then immersed in $3 \%$ glutaraldehyde. The shape and distribution of the $X$. oryzae pv. oryzae biofilms were observed by scanning electron microscopy (SEM). Each treatment had three replicates. 
Biofilm production was examined with crystal violet (CV) staining solution (Genevaux et al. 1996). Berberine solution with final concentrations of 1.64 and $10 \mu \mathrm{g} / \mathrm{ml}$ were mixed with $10^{8}$ $\mathrm{CFU} / \mathrm{ml}$ suspension of $X$. oryzae pv. oryzae for the treatments or a $1 \%$ methanol solution for the control. Then, $200 \mu \mathrm{l}$ of the mixture was pipetted into each well of a 96-well plate, which was statically incubated at $28^{\circ} \mathrm{C}$ for $48 \mathrm{~h}$. The bacterial suspension was emptied and the biofilm on the plate wall was washed twice with $0.9 \%$ normal saline. After air drying, the biofilm was stained with $200 \mu \mathrm{l}$ of $\mathrm{CV}(0.1 \%$, wt/vol) for $30 \mathrm{~min}$, and then unbound dye was removed by rinsing twice with $0.9 \%$ normal saline. Finally, the wellbound dye was solubilized in $200 \mu \mathrm{l}$ of glacial acetic acid (30\%, vol/ vol) and the absorbance was measured at $570 \mathrm{~nm}$ by a microplate reader (Infinite M200, TECAN, Switzerland). Each treatment had 10 replicates.

The cell surface hydrophobicity (CSH) of $X$. oryzae pv. oryzae was measured by the MATH method (Kumariya et al. 2015). $X$. oryzae pv. oryzae suspensions containing berberine $(10 \mu \mathrm{g} / \mathrm{ml})$ as the treatment group and $1 \%$ methanol as the control group were cultured for $30 \mathrm{~min}, 60 \mathrm{~min}, 120 \mathrm{~min}$, and $240 \mathrm{~min}$ and then centrifuged at 4,000g for $10 \mathrm{~min}$. The precipitate was diluted with PBS to $10^{9} \mathrm{CFU} / \mathrm{ml}$. A 5-ml aliquot of each bacterial suspension was mixed with $1.5 \mathrm{ml}$ of n-hexane and vigorously shaken for $60 \mathrm{~s}$. A 2-ml aliquot of the lower layer of the water solution after freezing for 15 min was used for measurement of the $\mathrm{OD}_{600}$; the value for PBS was taken as zero. Each treatment involved three replicates.

$$
\operatorname{CSH}(\%)=\left(1-A / A_{0}\right) \times 100
$$

where $A_{O}$ and $A$ are the $\mathrm{OD}_{600}$ values of the bacterial suspension before and after mixing with the n-hexane, respectively.

Extracellular polysaccharide production assays. Berberine was added to the bacterial suspension to obtain final berberine concentrations of 1.64 and $10 \mu \mathrm{g} / \mathrm{ml}$, and a $1 \%$ methanol solution (final concentration) was used as the control. After culturing for $24 \mathrm{~h}$, bacterial suspensions were diluted to $10^{8} \mathrm{CFU} / \mathrm{ml}$ and centrifuged at 4,000 $\times \mathrm{g}$ for $10 \mathrm{~min}$. A 5-ml aliquot of supernatant was mixed with $2 \mathrm{ml}$ of Sevag reagent (chloroform/butanol, 3:1) and then shaken vigorously to precipitate proteins. The mixture was incubated at $25^{\circ} \mathrm{C}$ for $1 \mathrm{~min}$ and then centrifuged at $4,000 \times g$ for $10 \mathrm{~min}$. The supernatant was treated with $2 \mathrm{ml}$ of Sevag reagent, and the above procedure was repeated. The precipitate was removed, and $1 \mathrm{ml}$ of supernatant was mixed with $3 \mathrm{ml}$ of $95 \%$ ethanol (1:3, $\mathrm{vol} / \mathrm{vol})$. The mixture was shaken and placed at $4^{\circ} \mathrm{C}$ for $20 \mathrm{~h}$ under static conditions and then centrifuged at $4,000 \times g$ for $10 \mathrm{~min}$. The crude extracellular polysaccharide (EPS) was obtained by drying the precipitate. The EPS was dissolved in distilled water, and the mass concentration was determined via an anthrone-sulfuric acid assay. Each treatment consisted of three replicates.

Extracellular enzyme activity assays. The effects of berberine on the extracellular enzyme activity of $X$. oryzae pv. oryzae were measured by a plate assay (Fan et al. 2014). Berberine was added to the cellulase, protease, and amylase detection media to obtain final berberine concentrations of $1.64,5$, and $10 \mu \mathrm{g} / \mathrm{ml}$. Plates containing $1 \%$ methanol were used as controls. Each plate was inoculated with a 1- $\mu$ l aliquot of $X$. oryzae pv. oryzae suspension at the center and incubated at $28^{\circ} \mathrm{C}$ for $48 \mathrm{~h}$. The activities of extracellular enzymes at different berberine concentrations were determined according to the ratio of the hydrolysis zone diameter (D) to colony diameter (d). Each treatment involved three replicates.

Effects of berberine on the T3SS. Adenylate cyclase protein translocation assays. To explore the possibility that berberine affects $X$. oryzae pv. oryzae translocation of type three secretion effector proteins (T3E) in plant cells via the T3SS, an adenylate cyclase (CyaA) fusion assay was performed as described in previous studies (Furutani 2009; Sory et al. 1995) with modifications. PXO_RS02310 has been determined to be a T3E gene by CyaA protein translocation assay (Furutani 2009). To construct plasmids harboring a $c y a A$ gene preceded by a promoter region and the $5^{\prime}$ coding region (125 amino acids) of the effector gene ( $\mathrm{PXO}$ RS02310), we amplified the $5^{\prime}$ coding and noncoding regions of the genes by PCR using appropriate primer sets with EcoRI and BamHI DNA polymerase. Then, the fragments were cloned into the plasmid pJAA (the plasmids harbor a promoterless 3xFLAG and cyaA gene preceded by unique EcoRI, SacI, KpnI, SmaI, BamHI, and XbaI sites) (Chen et al. 2014), generating plasmids with an effector::cyaA fusion gene. The plasmid was then introduced into $X$. oryzae pv. oryzae GX13 (WT) and named strain X. oryzae pv. oryzae RS02310-pJAA. The plasmid pJAA was introduced into X. oryzae pv. oryzae GX13 (WT) and named strain X. oryzae pv. oryzae pJAA.

Suspensions of the $X$. oryzae pv. oryzae RS021310-pJAA, $X$. oryzae pv. oryzae pJAA, and X. oryzae pv. oryzae GX13 strains at a concentration of $10^{8} \mathrm{CFU} / \mathrm{ml}$ were treated with berberine $(10 \mu \mathrm{g} / \mathrm{ml})$ and cultured for $12 \mathrm{~h}$, and a $1 \%$ methanol solution was used as the control. Fully expanded upper leaves of rice were inoculated at a concentration of $10^{8} \mathrm{CFU} / \mathrm{ml}$ by the leaf clipping method (Yang and Bogdanove. 2013). Each treatment consisted of three replicates, and each replicate contained $\geq 15$ leaves. Rice leaf sections ( $1 \mathrm{~cm}$ long) that included the inoculation site were collected 3 days after inoculation. A direct cAMP correlation enzyme immunoassay kit was used to process the leaf samples and measure the cAMP concentrations according to the manufacturer's instructions. The protein content of each sample was determined with a protein assay kit. The experiments were repeated three times.

Hypersensitive response assays. Strains of $X$. oryzae pv. oryzae RS021310-pJAA, X. oryzae pv. oryzae pJAA, and X. oryzae pv. oryzae GX13 were treated as described above and then infiltrated into leaves of Nicotiana tabacum and Nicotiana benthamiana by needleless syringes (Zhang et al. 2013b), each treatment consisted of three replicates. At $72 \mathrm{~h}$ after inoculation, the hypersensitive response (HR) triggered by $X$. oryzae pv. oryzae, which includes necrotic regions at the area of inoculation, was recorded. The experiments were repeated three times.

Effects of berberine on the cell structure of $X$. oryzae pv. oryzae. Effect of berberine on cell morphology by electron microscopy. Berberine at the MIC was mixed with bacterial suspension $\left(10^{8} \mathrm{CFU} / \mathrm{ml}\right)$, and a bacterial suspension treated with only $1 \%$ methanol served as the control. After culturing for 6,12 , or $24 \mathrm{~h}$, the suspension was centrifuged. The cells were washed three times with $0.2 \mathrm{M}$ PBS ( $\mathrm{pH} 7.4$ ) and then fixed with $2.5 \%$ glutaraldehyde in $0.2 \mathrm{M}$ PBS. The prepared samples were examined via SEM. The size of 30 bacteria was measured with the five-spotsampling method (five bacteria in each field of vision, each treatment consisted of six fields) and the length/width ratio of bacterial cell was determined.

Cell membrane permeability assay. A X. oryzae pv. oryzae suspension $\left(10^{8} \mathrm{CFU} / \mathrm{ml}\right)$ was treated with $10 \mu \mathrm{g} / \mathrm{ml}$ berberine for 0 , $2,4,6,8$, and $24 \mathrm{~h}$ and centrifuged at $4,000 \times g$ for $10 \mathrm{~min}$; a bacterial suspension treated with only $1 \%$ methanol served as the control. The supernatant was used to determine the electrical conductivity (supernatant was diluted 10 times) with a digital conductivity meter, (Leici DDS-11A; Shanghai Leici- Chuangyi Instrument and Meter Co., Ltd., China) and the lactate dehydrogenase (LDH) activity was determined with an assay kit. Each treatment had three replicates. The catalytic production of $1 \mathrm{nmol}$ of pyruvate/ml sample per minute is defined as one unit of LDH activity (U/liter).

To determine $\beta$-galactosidase activity, berberine and onitrophenyl-beta-D-galactopyranoside (ONPG) were added to the $X$. oryzae pv. oryzae suspension $\left(10^{8} \mathrm{CFU} / \mathrm{ml}\right)$; the final concentration of berberine was $0.625,1.25,2.5,5$, or $10 \mu \mathrm{g} / \mathrm{ml}$, and the concentration of ONPG was $1.5 \mathrm{mmol} / \mathrm{liter}$. A bacterial suspension treated with only $1 \%$ methanol, and $1.5 \mathrm{mmol} / \mathrm{liter}$ of ONPG served as the control. After being exposed to berberine for $2 \mathrm{~h}$, the culture was centrifuged at $4,000 \times g$ for $10 \mathrm{~min}$. The optical density at $420 \mathrm{~nm}\left(\mathrm{OD}_{420}\right)$ of the supernatant was determined with a $\mathrm{UV}$-visible spectrometer. $\beta$-Galactosidase can hydrolyze ONPG to 
o-nitrophenol (ONP). The $\mathrm{OD}_{420}$ of the supernatant was positively correlated with the concentration of $\mathrm{ONP}$, and the $\mathrm{OD}_{420}$ of the supernatant reflects the activity of $\beta$-galactosidase in bacterial culture medium treated with berberine at different concentrations. Each treatment involved three replicates.

Energy metabolism assays. Berberine solution with concentration of $1.64,5$, or $10 \mu \mathrm{g} / \mathrm{ml}$ was mixed with a bacterial suspension, and a $1 \%$ methanol solution was used as the control. After culturing for $4 \mathrm{~h}$, the bacterial suspensions were centrifuged at $4,000 \times g$ for $10 \mathrm{~min}$. The pyruvate levels in the supernatant were determined by 2, 4-dinitrophenylhydrazine colorimetry based on the manufacturer's instructions for commercial kits. The bacterial suspension was shaken for $24 \mathrm{~h}$, and $1.5 \mathrm{ml}$ of each treatment was centrifuged at 4,000 $\times \mathrm{g}$ for $10 \mathrm{~min}$ and resuspended in PBS to the original volume, followed by sonication for $10 \mathrm{~min}$ (vibration for $2 \mathrm{~s}$, with an $8 \mathrm{~s}$ break) at $300 \mathrm{~W}$ with an ultrasonic cell disrupter. Then, the suspension was centrifuged at $4^{\circ} \mathrm{C}$ at $12,000 \mathrm{~g}$ for $10 \mathrm{~min}$, and the resulting supernatants represented the total protein solution or crude enzyme solution. The malate dehydrogenase (MDH) activity, total protein content, and ATP content were determined with kits. Each treatment was replicated three times.

One unit of MDH activity was defined as the amount of enzyme in $1 \mathrm{ml}$ of bacterial suspension that caused a reduction of 0.01 absorbance units in 1 min compared with the control reaction.

Transcriptomic analysis. Sample preparation and Illumina sequencing. Berberine was added to the bacterial suspension to obtain a final berberine concentration of $10 \mu \mathrm{g} / \mathrm{ml}$, and a $1 \%$ methanol solution (final concentration) was used as the control. The bacterial suspension was cultured for $12 \mathrm{~h}$, and the bacteria were collected and used for RNA extraction. Each treatment was replicated two times; the treatment samples were named MIC1, MIC2, CK1, and CK2. Total RNA was extracted with TRIzol (Invitrogen, Carlsbad, CA) according to the manufacturer's instructions. RNA degradation and contamination were monitored on $1 \%$ agarose gels. RNA purity was checked with a NanoPhotometer spectrophotometer (IMPLEN, CA, U.S.A.). RNA concentration was quantified by the Qubit assay, and RNA integrity was determined using an Agilent 2100 bioanalyzer. The RNA samples were then sent to Beijing Novogene Bioinformation Technology Co., Ltd. (Beijing, China) for Illumina sequencing.

Illumina sequencing was carried out on an Illumina HiSeqTM 2500 platform to obtain the original data (raw data). The whole genome of the WT strain PXO99A of X. oryzae pv. oryzae was used as the reference sequence for genome mapping analysis with Bowtie2. After analysis of gene expression levels by HTSeq software and analysis of differential expression by DESeq, gene ontology (GO) enrichment analysis and KEGG enrichment analysis were used to determine the functional classification of enriched GO terms and the main biochemical metabolic pathways and signal transduction pathways associated with significantly enriched differentially expressed genes (DEGs).

Validation of the selected DEGs by quantitative reverse transcription PCR. Total RNA was extracted from $1 \mathrm{ml}$ of $X$. oryzae pv. oryzae suspension cultured $\left(10^{8} \mathrm{CFU} / \mathrm{ml}\right)$ in NB with $10 \mu \mathrm{g} / \mathrm{ml}$ of berberine and $1 \%$ methanol for $12 \mathrm{~h}$ using TRIzol (Invitrogen, Carlsbad, CA). Then 100 ng of this RNA was used for reverse transcription by HiScript Q Select RT SuperMix for qPCR (+gDNA wiper) (Vazyme, China). Quantitative real-time PCR was performed using the ChamQTM Universal SYBR qPCR master mix (Vazyme, China). PCR for each of the three biological replicates was performed in technical triplicate. The thermal cycling reaction was carried out on a qTOWER 2.2 (Germany) as follows: 1 cycle of reverse transcription at $50^{\circ} \mathrm{C}$ for $30 \mathrm{~min}$, followed by denaturation at $95^{\circ} \mathrm{C}$ for $30 \mathrm{~s}$ and 40 cycles of $95^{\circ} \mathrm{C}$ for $10 \mathrm{~s}$ and $60^{\circ} \mathrm{C}$ for $30 \mathrm{~s}$. We obtained a melting curve from 60 to $95^{\circ} \mathrm{C}$ by increasing the temperature stepwise by $0.5^{\circ} \mathrm{C}$ every $5 \mathrm{~s}$ to test the specificity of the amplified product. The expression levels of selected DEGs were normalized to those of an internal reference gene, 16S ribosomal
RNA. The relative expression levels of the genes were calculated via the $2^{-\Delta \Delta C t}$ method. The primers were designed with the NCBI Primer Design Tool with the PXO99A genome as a reference sequence. The genes and primer sequences used for quantitative reverse transcription PCR are shown in Supplementary Table S1.

Statistical analysis. Data were subjected to analysis of variance in SAS version 6.08. Mean comparisons were conducted via a Fisher's least significant difference (LSD) test at $P=0.05$. Percentage values were transformed to arcsine $\sqrt{ } \%$ for statistical analysis. Standard error and LSD results were recorded.

\section{RESULTS}

In vitro test for antibacterial activity of berberine against $X$. oryzae pv. oryzae. At $10^{7} \mathrm{CFU} / \mathrm{ml}$ of $X$. oryzae pv. oryzae bacterial solution (initial concentration), the inhibitory rate and toxicity regression of berberine against $X$. oryzae pv. oryzae are shown in Table 1 , and the $\mathrm{IC}_{50}$ value was $1.64 \mu \mathrm{g} / \mathrm{ml}$. The MIC and $\mathrm{MBC}$ of berberine against $X$. oryzae pv. oryzae were 10 and 40 $\mu \mathrm{g} / \mathrm{ml}$, respectively (Table 2 ).

At $10^{7} \mathrm{CFU} / \mathrm{ml}$ of $X$. oryzae pv. oryzae (Supplementary Fig. $\mathrm{S} 1 \mathrm{~A}$ ), the area under the growth progress curve (AUGPC) of $X$. oryzae pv. oryzae under $1.64 \mu \mathrm{g} / \mathrm{ml}$ berberine treatments was smaller than that of the control before $36 \mathrm{~h}$, but no significant difference was observed after $36 \mathrm{~h}$. The bacteria could not regenerate during the observation period under the $10 \mu \mathrm{g} / \mathrm{ml}$ berberine treatment, and the culture medium remained clarified. When the initial bacterial concentration was $10^{8} \mathrm{CFU} / \mathrm{ml}$ (Supplementary Fig. S1B), there were no significant differences between the AUGPC of X. oryzae pv. oryzae treated with $1.64 \mu \mathrm{g} / \mathrm{ml}$ berberine and the control group at $76 \mathrm{~h}$, but the AUGPC of $X$. oryzae pv. oryzae treated with $10 \mu \mathrm{g} / \mathrm{ml}$ berberine was smaller than that of the control group. This indicated that, at the same berberine treatment concentration, the AUGPC of the pathogen varied with the initial concentration of the pathogen. Therefore, throughout the study, we used $10^{8} \mathrm{CFU} / \mathrm{ml}$ of $X$. oryzae pv. oryzae as the initial concentration to test physiological and transcriptional responses of $X$. oryzae pv. oryzae to berberine.

Berberine reduces the virulence of $X$. oryzae pv. oryzae and decreases $X$. oryzae pv. oryzae infection in planta. At the 20th day after inoculation, the average lesion length of the berberine treatment was $3.2 \pm 0.9 \mathrm{~cm}$, which was significantly shorter than that of the WT treatment $(5.5 \pm 1.1 \mathrm{~cm}, P<0.05)$ (Supplementary Fig. S2), indicating that the virulence of $X$. oryzae pv. oryzae was reduced after berberine treatment.

At 3 to $11 \mathrm{dpi}$, the $X$. oryzae pv. oryzae population in rice leaves inoculated with berberine-treated $X$. oryzae pv. oryzae was significantly lower than in leaves inoculated with untreated $X$. oryzae pv. oryzae (Fig. 1).

Berberine inhibited BLB lesions in $X$. oryzae pv. oryzaeinoculated rice leaves. On the 15 th day after inoculation, the inhibition rate of $0.1,0.25$, and $0.5 \mathrm{~g} /$ liter berberine and $0.4 \mathrm{~g} /$ liter bismerthiazol on BLB lesion expansion was, respectively, 13.0, 48.6, 84.2, and $85.9 \%$ (Table 3). At $0.5 \mathrm{~g} /$ liter, berberine treatment inhibited BLB lesion expansion effectively and was not significantly different from the $0.4 \mathrm{~g} /$ liter bismerthiazol treatment.

Effects of berberine on virulence factors of $X$. oryzae $\mathrm{pv}$. oryzae. Berberine inhibits biofilm formation of $\mathrm{X}$. oryzae $p v$. oryzae. SEM imaging of biofilms with 12 random fields of view showed that the biofilm of the control group was dense and thick (Fig. 2A), whereas the berberine-treated group did not form a distinct biofilm, and only a few bacteria adhered to the carrier surface (Fig. 2B). Furthermore, the result of titer plate-based CV staining revealed a significant decrease in biofilm production in a concentration-dependent manner in berberine-treated $X$. oryzae $\mathrm{pv}$. oryzae cells; the $\mathrm{OD}_{570}$ values of the $0,16.4$, and $10 \mu \mathrm{g} / \mathrm{ml}$ berberine treatments were $0.34 \pm 0.01,0.26 \pm 0.01$, and $0.24 \pm 0.01$, respectively (Fig. 2C). 
$\mathrm{CSH}$ is associated with the attachment ability and biofilm formation of $X$. oryzae pv. oryzae (Blanco et al. 2010). Berberine at $10 \mu \mathrm{g} / \mathrm{ml}$ significantly reduced the $\mathrm{CSH}$ of $X$. oryzae pv. oryzae (Table 4). After 2 and $4 \mathrm{~h}$ of berberine treatment, the $\mathrm{CSH}$ values of $X$. oryzae pv. oryzae were 9.77 and $5.35 \%$, and those of the control were 17.65 and $12.50 \%$, respectively. These results suggested that berberine may inhibit biofilm formation by reducing the $\mathrm{CSH}$ of $X$. oryzae pv. oryzae.

Berberine reduces EPS production in X. oryzae $p v$. oryzae. After treatment with 1.64 and $10 \mu \mathrm{g} / \mathrm{ml}$ of berberine, the EPS content per $10^{8} \mathrm{CFU}$ of bacteria was $1.74 \pm 0.34$ and $1.97 \pm 0.27 \mu \mathrm{g}$, respectively, which was significantly lower than that of the control $(2.63 \pm 0.31 \mu \mathrm{g})$ at $P=0.05$ based on Fisher's LSD test. These results

TABLE 1. Toxicity regression of berberine against Xanthomonas oryzae pv. oryzae

\begin{tabular}{lcccc}
\hline $\begin{array}{l}\text { Berberine } \\
\text { concentration } \\
(\mu \mathrm{g} / \mathrm{ml})\end{array}$ & $\begin{array}{c}\text { Inhibition } \\
(\%)\end{array}$ & $\begin{array}{c}\text { Toxicity } \\
\text { regression } \\
(Y=\mathrm{a}+\mathrm{b} X)^{\mathrm{z}}\end{array}$ & $\begin{array}{c}\text { Correlation } \\
\text { coefficient }\end{array}$ & $\begin{array}{c}\text { Half maximal } \\
\text { inhibitory } \\
\text { concentration } \\
(\mu \mathrm{g} / \mathrm{ml})\end{array}$ \\
\hline 0.50 & 4.18 & $Y=4.2898+$ & 0.9986 & 1.64 \\
1.00 & 25.96 & $3.2710 X$ & & \\
2.00 & 62.16 & & & \\
4.00 & 87.14 & & & \\
8.00 & 98.94 & & \\
\hline
\end{tabular}

z Toxicity regression equation $Y=\mathrm{a}+\mathrm{b} X$, where $Y$ is the inhibitory probit value and $X$ is concentration logarithm of berberine.

TABLE 2. The minimum inhibitory concentration and minimum bactericidal concentration of berberine against Xanthomonas oryzae pv. oryzae

\begin{tabular}{lcc}
\hline & $\begin{array}{c}\text { Turbidity of nutrient broth } \\
\text { culture medium after } \\
\text { treatment with } \\
\text { berberine for } 24 \mathrm{~h}\end{array}$ & $\begin{array}{c}\text { The growth } \\
\text { of bacteria on } \\
\text { nutrient agar plate }\end{array}$ \\
\hline berberine $(\mu \mathrm{g} / \mathrm{ml})$ & Turbid & + \\
1.25 & Turbid & + \\
2.5 & Turbid & + \\
5 & Clarified & + \\
10 & Clarified & + \\
20 & Clarified & - \\
40 & Clarified & - \\
\hline
\end{tabular}

$\mathrm{z}$ - represents sterile growth, and + represents the growth of bacteria.

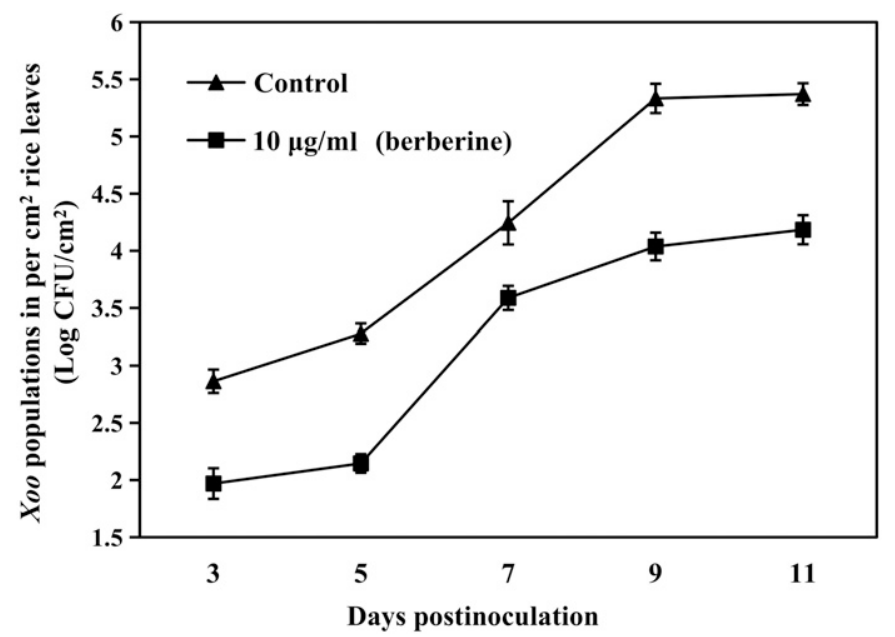

Fig. 1. Xanthomonas oryzae pv. oryzae populations $/ \mathrm{cm}^{2}$ rice leaves. All experiments were repeated three times, each value is the mean and standard error of three separate determinations. suggested that berberine can reduce EPS production in X. oryzae pv. oryzae in a dose-independent manner.

Berberine suppresses the secretion of extracellular hydrolase in $\mathrm{X}$. oryzae $p v$. oryzae. The $\mathrm{D} / \mathrm{d}$ values of cellulase under $0 \mu \mathrm{g} / \mathrm{ml}$ (control), $1.64,5$, and $10 \mu \mathrm{g} / \mathrm{ml}$ berberine treatment were 3.82,3.30, 2.43, and 2.02; those of protease were 2.19, 2.50, 1.33, and 1.33; and those of amylase were 2.98, 2.91, 2.09, and 2.29, respectively (Fig. 3 ). The D/d values of extracellular cellulase, protease, and amylase in the 5 and $10 \mu \mathrm{g} / \mathrm{ml}$ berberine treatments were significantly lower than those in the control treatments. This result indicated that berberine was able to suppress the secretion of extracellular enzyme in the bacterium $X$. oryzae pv. oryzae, and the higher rates of berberine had an increased effect.

Effect of berberine on the cell structure of $X$. oryzae pv. oryzae. Effect of berberine on cell morphology by SEM. SEM images showed that the morphology of $X$. oryzae pv. oryzae cells treated with berberine at $10 \mu \mathrm{g} / \mathrm{ml}$ changed markedly compared with that of control's cells (Fig. 4). The X. oryzae pv. oryzae cells of control were short and rod shaped, with rounded ends and smooth surfaces after 6 to $24 \mathrm{~h}$ of culture (Fig. 4A). However, the berberinetreated cells exhibited elongation after 6, 12, and $24 \mathrm{~h}$ (Fig. 4B to D). For 30 bacteria, the length/width ratios of bacterial cells after 6,12 , and $24 \mathrm{~h}$ of berberine treatment were $3.7,4.5$, and 5.6, respectively. However, the ratio of the control cell during this period of time remained at 3.1 to 3.4 , which was significantly lower than that of the bacteria treated with berberine (Fig. 4E), indicating that berberine could damage the cell morphology of $X$. oryzae pv. oryzae, and the effect increased with duration of treatment.

Effect of berberine on the membrane permeability of $\mathrm{X}$. oryzae $p v$. oryzae. There was no significant difference in electrical conductivity between different concentrations of berberine treatment and the control group before $8 \mathrm{~h}$ of culture. The conductivity of the $X$. oryzae pv. oryzae culture medium treated with $10 \mu \mathrm{g} / \mathrm{ml}$ berberine for $24 \mathrm{~h}$ was $142.20 \pm 0.80 \mu \mathrm{S} / \mathrm{cm}$ and was significantly different $(P=0.05)$ from that of the other treatments (Fig. 5), indicating that berberine can change the permeability of cell membrane and lead to electrolyte exosmosis when the concentration of berberine was $>10 \mu \mathrm{g} / \mathrm{ml}$ and the treating time was $>24 \mathrm{~h}$.

LDH and $\beta$-galactosidase are an intracellular enzyme that does not leak out from cells. The LDH activity after treatment with $10 \mu \mathrm{g} /$ $\mathrm{ml}$ of berberine for $2,4,8$, and $24 \mathrm{~h}$ was $2.36 \pm 0.092,2.96 \pm 0.18$, $3.67 \pm 0.11$, and $4.32 \pm 0.19 \mathrm{U} /$ liter, respectively, and the LDH activity in the control was $1.58 \pm 0.23,2.72 \pm 0.17,2.17 \pm 0.19$, and $2.07 \pm 0.22 \mathrm{U} /$ liter, respectively. The activity of LDH in the culture

TABLE 3. Effects of berberine on bacterial leaf blight lesions ${ }^{y}$

\begin{tabular}{lcc}
\hline & $\begin{array}{c}\text { Inhibition rate } \\
\text { of 10th day after } \\
\text { inoculation } \\
(\%)( \pm \mathrm{SE})^{\mathrm{z}}\end{array}$ & $\begin{array}{c}\text { Inhibition rate of } \\
\text { 15th day after } \\
\text { inoculation } \\
(\%)( \pm \mathrm{SE})\end{array}$ \\
\hline $0.1 \mathrm{~g} /$ liter berberine & $18.5 \pm 3.8 \mathrm{c}$ & $13.0 \pm 8.8 \mathrm{c}$ \\
$0.25 \mathrm{~g} /$ liter berberine & $45.1 \pm 2.9 \mathrm{~b}$ & $48.8 \pm 7.1 \mathrm{~b}$ \\
$0.5 \mathrm{~g} /$ liter berberine & $91.1 \pm 2.8 \mathrm{a}$ & $84.2 \pm 2.9 \mathrm{a}$ \\
$0.4 \mathrm{~g} /$ liter bismerthiazol & $96.3 \pm 1.8 \mathrm{a}$ & $85.9 \pm 1.4 \mathrm{a}$ \\
\hline
\end{tabular}

y Rice plants were inoculated with $X$. oryzae pv. oryzae GX13 and were sprayed with $0.1,0.25$, and $0.5 \mathrm{~g} /$ liter berberine solution 1 day after inoculation. Plants sprayed with $1 \%$ methanol served as controls, and bismerthiazol at a concentration of $0.4 \mathrm{~g} /$ liter was used as the bactericide control.

$\mathrm{z}$ The lengths of bacterial leaf blight lesions were measured 10 and 15 days after inoculation, and the inhibition rates of lesion expansion on leaves were calculated. Inhibition rates were calculated as (lesion length of the reference control - lesion length of the pesticide group)/lesion length of the reference control $\times 100$. Inhibition rates were transformed to arcsine $\sqrt{ } \%$ for statistical analysis. Each value is the mean and standard error (SE) of three separate determinations. Means within columns followed by the same letter are not significantly different $(P=0.05)$ according to Fisher's least significant difference test. 
medium treated with berberine was higher than that of the control, and the difference was the greatest at $24 \mathrm{~h}$, which indicated that berberine had an irreversible effect on the cell membrane permeability of $X$. oryzae pv. oryzae.

In addition, the $\beta$-galactosidase activity (positive correlation with $\mathrm{OD}_{420}$ ) in the $X$. oryzae pv. oryzae culture medium was altered by berberine treatment in a dose-dependent manner and was higher than that in the control group (Table 5). These results indicate that berberine can damage the cell membrane and change the permeability of $X$. oryzae pv. oryzae.

Berberine affects the energy metabolism of $X$. oryzae $\mathrm{pv}$. oryzae. The effects of berberine on energy metabolism were analyzed by measuring the pyruvate content, MDH activity, and ATP content of $X$. oryzae pv. oryzae. The results are shown in
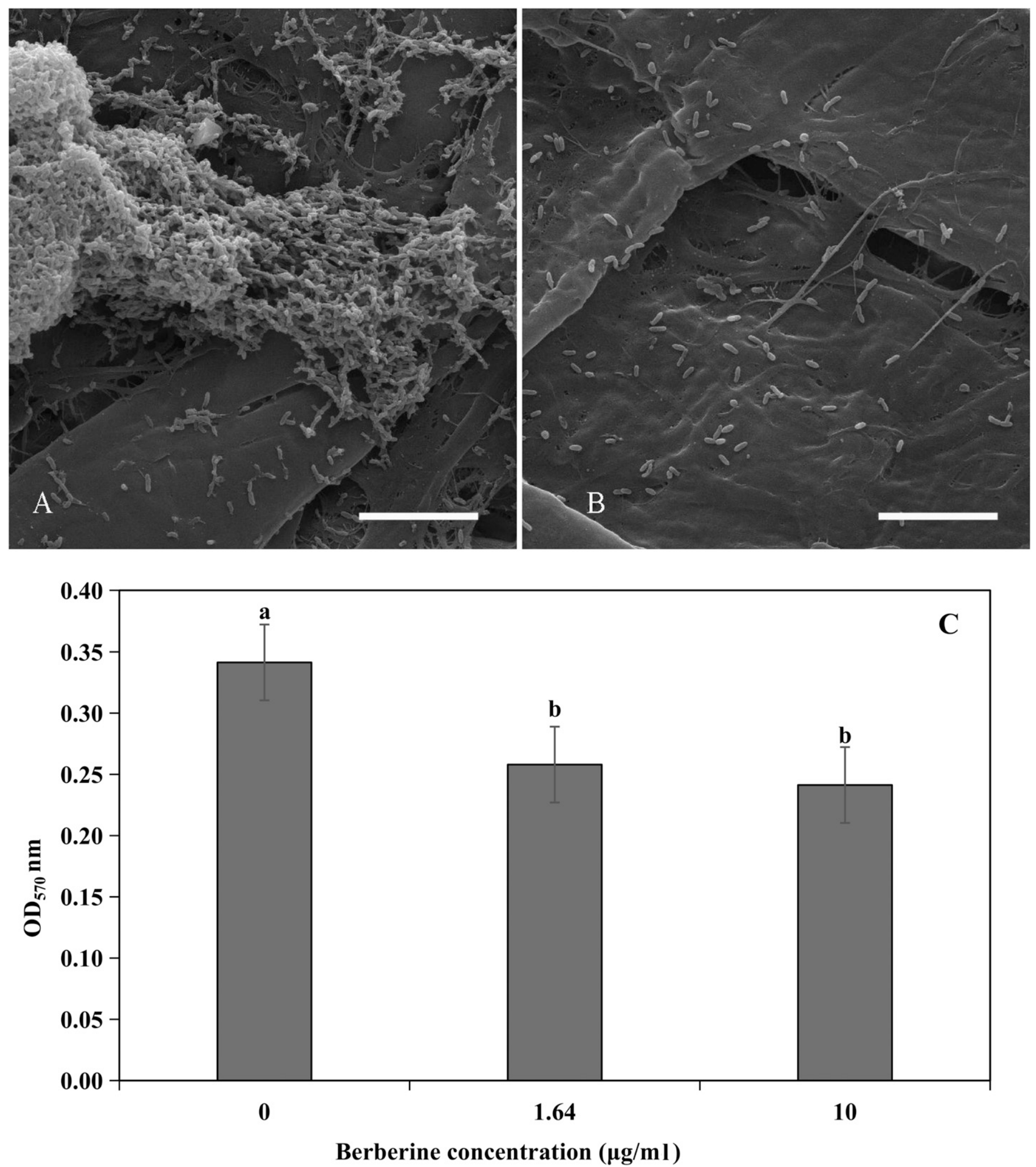

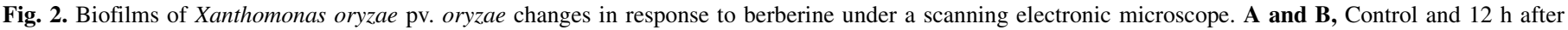
treatment with berberine, respectively. Scale bar $=10 \mu \mathrm{m}$. C, The production of biofilm determined by crystal violet staining. 
Table 6. The pyruvate content in $X$. oryzae pv. oryzae increased substantially in a dose-dependent manner after exposure to berberine for $4 \mathrm{~h}$. There were significant differences between the $5 \mu \mathrm{g} / \mathrm{ml}$ berberine treatment and the control. Significant changes were observed in the MDH activity and ATP content of $X$. oryzae $\mathrm{pv}$. oryzae after exposure to different concentrations of berberine for $24 \mathrm{~h}$. Interestingly, this stimulatory effect was observed at very low berberine concentrations $(1.64 \mu \mathrm{g} / \mathrm{ml})$. Berberine treatment increased the ATP content compared with that in the control. There were significant differences between the berberine treatments at $1.64,5$, and $10 \mu \mathrm{g} / \mathrm{ml}$. These results indicated that the energy metabolism of $X$. oryzae pv. oryzae was altered by berberine.

Transcriptomic analysis. After elimination of low-quality data, $14,132,410,16,675,798,18,501,822$, and 17,517,468 clean reads were generated for the berberine-treated $X$. oryzae groups MIC1 and MIC2 and control X. oryzae groups CK1 and CK2, respectively. Clean reads were mapped to the PXO99A genome sequence in the NCBI GenBank database with 67.24, 69.67, 97.28, and $97.54 \%$, matched reads to NCBI annotated gene regions for $X$. oryzae groups MIC1, MIC2, CK1, and CK2, respectively, and the Q30 percentages were 90.50, 90.43, 92.23, and 92.49\%, respectively (Supplementary Table S2).

Analysis of gene expression levels and differences in gene expression. Compared with the transcriptomic library of $X$. oryzae CK, 794 genes (padj $\leq 0.05$ and $\mid \log _{2}$ FoldChange $\mid \geq 2$ ) were identified as DEGs in strain GX13 of $X$. oryzae pv. oryzae under berberine $(10 \mu \mathrm{g} / \mathrm{ml})$ treatment, comprising 534 upregulated genes and 260 downregulated genes (Supplementary Fig. S3).

$G O$ enrichment analysis of DEGs. According to GO functional enrichment analysis, 1401, 296, and 822 terms were enriched in biological process, cellular component, and molecular function, respectively. The most significantly enriched terms are shown in Supplementary Table S3.

$K E G G$ enrichment analysis of DEGs. The pathways enriched for the $X$. oryzae MIC versus $X$. oryzae CK upregulated DEGs were ribosome, oxidative phosphorylation, and bacterial chemotaxis. The downregulated DEGs were clustered mainly in four pathways: starch, sucrose, fructose, and mannose metabolism (Supplementary Table S4).

DEGs involved in virulence. The virulence factors of $X$. oryzae pv. oryzae include mainly biofilm formation (Sahu et al. 2018), extracellular enzymes (Sun et al. 2005), type III effectors (Zhang et al. 2013a), and two-component systems (Lee et al. 2008). The expression of gumB (PXO_RS15915) and gumC (PXO_RS15910), which are associated with EPS synthesis, was downregulated. In the bacterial secretion system (pathway ID: xop03070), 11 genes encoding the type II secretion system, such as gspD ( $\mathrm{PXO}_{-}$ RS20800), $g s p E$ (PXO_RS01740), and $g s p F$ (PXO_RS20845), were downregulated, and the genes hrcC (PXO_RS00410), hrcJ (PXO_ RS00370), $h r c N$ (PXO_RS00360), $h r c R$ (PXO_RS00345), $h r c \bar{Q}$ (PXO_RS00350), T3S effector genes (PXO_RS02310, PXO_ RS25150), and hrpB4 (PXO_RS00385), which are associated with the type III secretion system, were also downregulated. In the twocomponent systems (pathway ID: xop02020), the genes raxH2 (PXO_RS22690) and raxR2 (PXO_RS22695), which are associated with the PhoPQ two-component system, were upregulated. The gene rpfF (PXO_RS08285), which encodes the diffusible signal factor (DSF) synthase, was upregulated, but the gene $c l p$ (PXO_RS02870), which encodes the cAMP receptor-like protein, was downregulated.

DEGs involved in cell membrane and cell division. Lipopolysaccharides and fatty acids are important components of cell membranes. It was found that the genes lpxH (PXO_RS19900), lpxK (PXO_RS10720), and kdtA (PXO_RS20465), which are involved in lipopolysaccharide biosynthesis (pathway ID: xop00540), were downregulated. The genes fabB (PXO_ RS22470) and $f a b G\left(\mathrm{PXO}_{\mathrm{RS} 01035)}\right.$ were downregulated in fatty acid biosynthesis (pathway ID: xop00061). Cell division-related genes zapE (PXO_RS01775), ftsQ(PXO_RS04855), zapA (PXO_
RS19285), and ftsA (PXO_RS04860) were downregulated, but recA (PXO_RS07900), encoding DNA recombination protein RecA, and lexA (PXO_RS17410), encoding LexA repressor 1, were upregulated in the salt overly sensitive (SOS) pathway.

DEGs involved in energy metabolism. Glycolysis-related genes (pathway ID: xop00010), including xanA (PXO_RS22280, encoding phosphomannomutase), pyk (PXO_RS17285, encoding pyruvate kinase), and pgk (PXO_RS17295, encoding phosphoglycerate kinase), were downregulated. Genes associated with pyruvate metabolism (pathway ID: xop00620), including lpdA (PXO_ RS21420, encoding dihydrolipoamide dehydrogenase), pdh $\alpha$ (PXO_RS03585, encoding pyruvate dehydrogenase [E1] alpha subunit), and $p d h \beta$ (PXO_RS03590, encoding pyruvate dehydrogenase [E1] beta subunit), were downregulated. The gene $m d h$ (PXO_ RS20105, encoding malate dehydrogenase), which is associated with the tricarboxylic acid (TCA) cycle (pathway ID: xop00020), was downregulated. Furthermore, genes associated with oxidative phosphorylation (pathway ID: xop00190), including the genes nuoA (PXO_RS16465), пиоB (PXO_RS16460), and nиоH (PXO_ RS16430), encoding the NADH dehydrogenase complex, were upregulated, as were the genes atpF (PXO_RS21390), atpC ( $\mathrm{PXO}_{-}$ RS21365), and atpB (PXO_RS21400), encoding ATP synthase.

DEGs involved in chemotaxis. Genes associated with bacterial chemotaxis, including cheY (PXO_RS08445), cheB (PXO_ RS06355), cheW (PXO_RS08365), motD (PXO_RS08465), mot $\bar{A}$ (PXO_RS21585), and $m c p$ genes (PXO_RS06375, PXO_RS11220 and PXO_RS08405, etc.), encoding methyl-accepting chemotaxis proteins (MCPs), were upregulated.

TABLE 4. Effects of berberine on cell surface hydrophobicity (CSH) of Xanthomonas oryzae pv. oryzae

\begin{tabular}{lcc}
\hline Time $(\mathrm{min})$ & $\begin{array}{c}\text { CSH of } X \text {. oryzae } \\
\text { pv. oryzae treated with } \\
\text { control }(\%)( \pm \mathrm{SE})^{\mathrm{z}}\end{array}$ & $\begin{array}{c}\text { CSH of } X \text {. oryzae pv. oryzae } \\
\text { treated with } 10 \mu \mathrm{g} / \mathrm{ml} \\
\text { berberine }(\%)( \pm \mathrm{SE})\end{array}$ \\
\hline 30 & $0.45 \pm 0.64 \mathrm{a}$ & $1.59 \pm 0.79 \mathrm{a}$ \\
60 & $16.02 \pm 0.71 \mathrm{a}$ & $11.42 \pm 0.53 \mathrm{~b}$ \\
120 & $17.65 \pm 0.66 \mathrm{a}$ & $9.77 \pm 0.85 \mathrm{~b}$ \\
240 & $12.50 \pm 0.76 \mathrm{a}$ & $5.35 \pm 0.95 \mathrm{~b}$ \\
\hline
\end{tabular}

${ }^{\mathrm{z}}$ Each value is the mean and standard error (SE) of three separate determinations. Means within line followed by the same letter are not significantly different $(P=0.05)$ according to Fisher's least significant difference test.

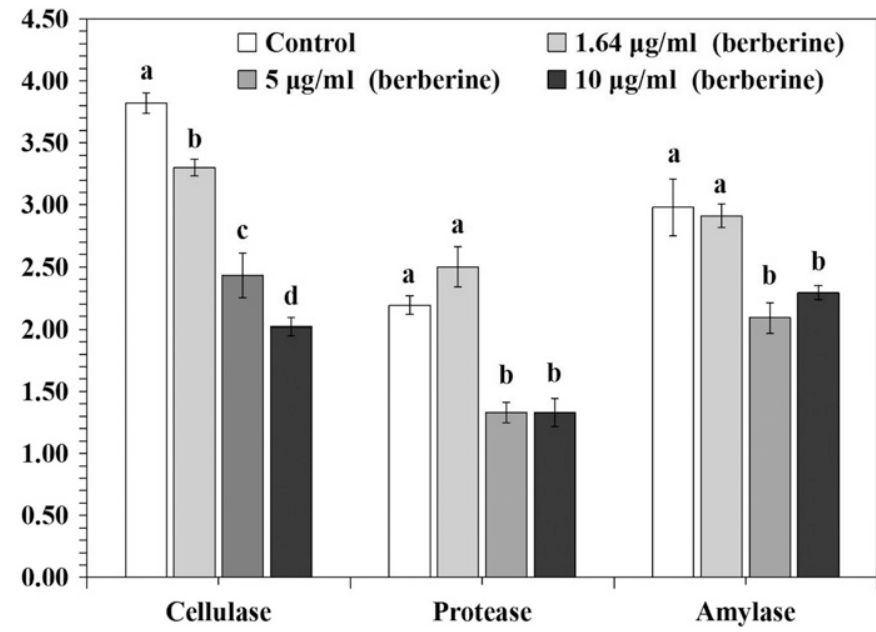

Fig. 3. Effect of berberine on activities of extracellular enzymes of Xanthomonas oryzae pv. oryzae. $D$ and $d$ indicate hydrolysis zone diameter and colony diameter, respectively. Means followed by the same letter are not significantly different at $P=0.05$ based on Fisher's least significant difference test. The error bar represents the standard error of mean. 
The expression data for the above DEGs are shown in Supplementary Table S5. To verify the accuracy of transcriptome sequencing, gene expression in $X$. oryzae pv. oryzae was validated by performing quantitative reverse transcription PCR for a selection of 10 DEGs involved in virulence, 9 DEGs involved in cell membrane and cell division, 8 DEGs involved in energy metabolism, and 4 DEGs involved in chemotaxis after treatment with berberine $(10 \mu \mathrm{g} /$ $\mathrm{ml}$ ) for $12 \mathrm{~h}$. The results showed that the expression pattern of each tested gene was similar to that observed by transcriptome sequencing (Supplementary Figs. S5, S6, S7, and S8).

Berberine reduces T3E secretion via T3SS of $X$. oryzae pv. oryzae. The strains $X$. oryzae pv. oryzae RS02310-pJAA, with the effector::cyaA fusion gene, and $X$. oryzae pv. oryzae pJAA, with an empty vector (pJAA), were constructed. PCR and enzyme digestion confirmation of transconjugants and the recombinant plasmid are shown in Supplementary Fig. S4. Three days after inoculation, cAMP levels in the rice leaves inoculated with the $X$. oryzae pv. oryzae RS021310-pJAA strain were significantly higher than those of leaves inoculated with strains $X$. oryzae $\mathrm{pv}$. oryzae pJAA and $X$. oryzae pv. oryzae GX13. The results suggest that, during infection, the effector::CyaA construct was transported into the rice leaf cells. As predicted, cAMP levels in the rice leaves that were inoculated with strain $X$. oryzae pv. oryzae RS021310pJAA and treated with berberine were significantly lower than that of control (Table 7), indicating that berberine affected T3E secretion via the T3SS and reduced effector translocation of $X$. oryzae pv. oryzae.

Berberine weakened the $H R$ in nonhost plants of $X$. oryzae pv. oryzae. A tobacco inoculation assay was performed to test whether berberine affects induction of the HR in nonhost plants. The $X$. oryzae pv. oryzae $\mathrm{GX} 13, X$. oryzae pv. oryzae RS021310-pJAA, and X. oryzae pv. oryzae pJAA strains were inoculated into 4-week-old Nicotiana tabacum and Nicotiana benthamiana leaves at a cell density of $10^{8} \mathrm{CFU} / \mathrm{ml}$ by needleless infiltration. The results showed that control (1\% methanol treatment) strains induced the HR in tobacco leaves at $72 \mathrm{~h}$ after inoculation, whereas the strains treated with berberine elicited a weakened HR compared with control strains (Fig. 6). These results indicate that berberine weakened the HR, and the effector::CyaA construct do not affect the HR in nonhost plants of $X$. oryzae pv. oryzae.

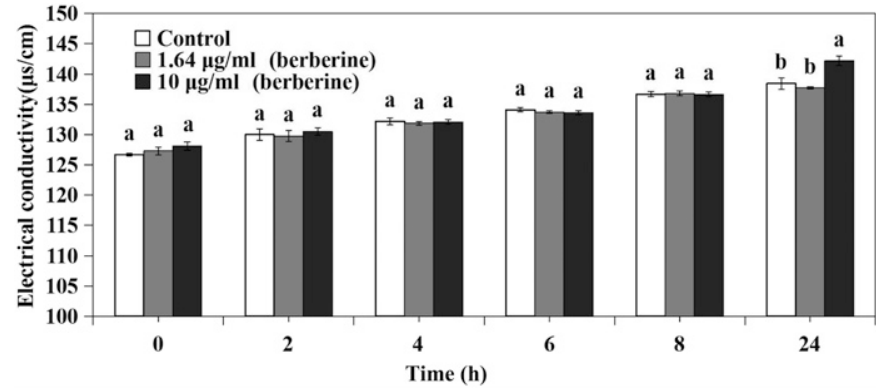

Fig. 5. Effects of berberine on electrical conductivity in the culture supernatant of Xanthomonas oryzae pv. oryzae. Means followed by the same letter are not significantly different at $P=0.05$ based on Fisher's least significant difference test. The error bar represents the standard error of mean.
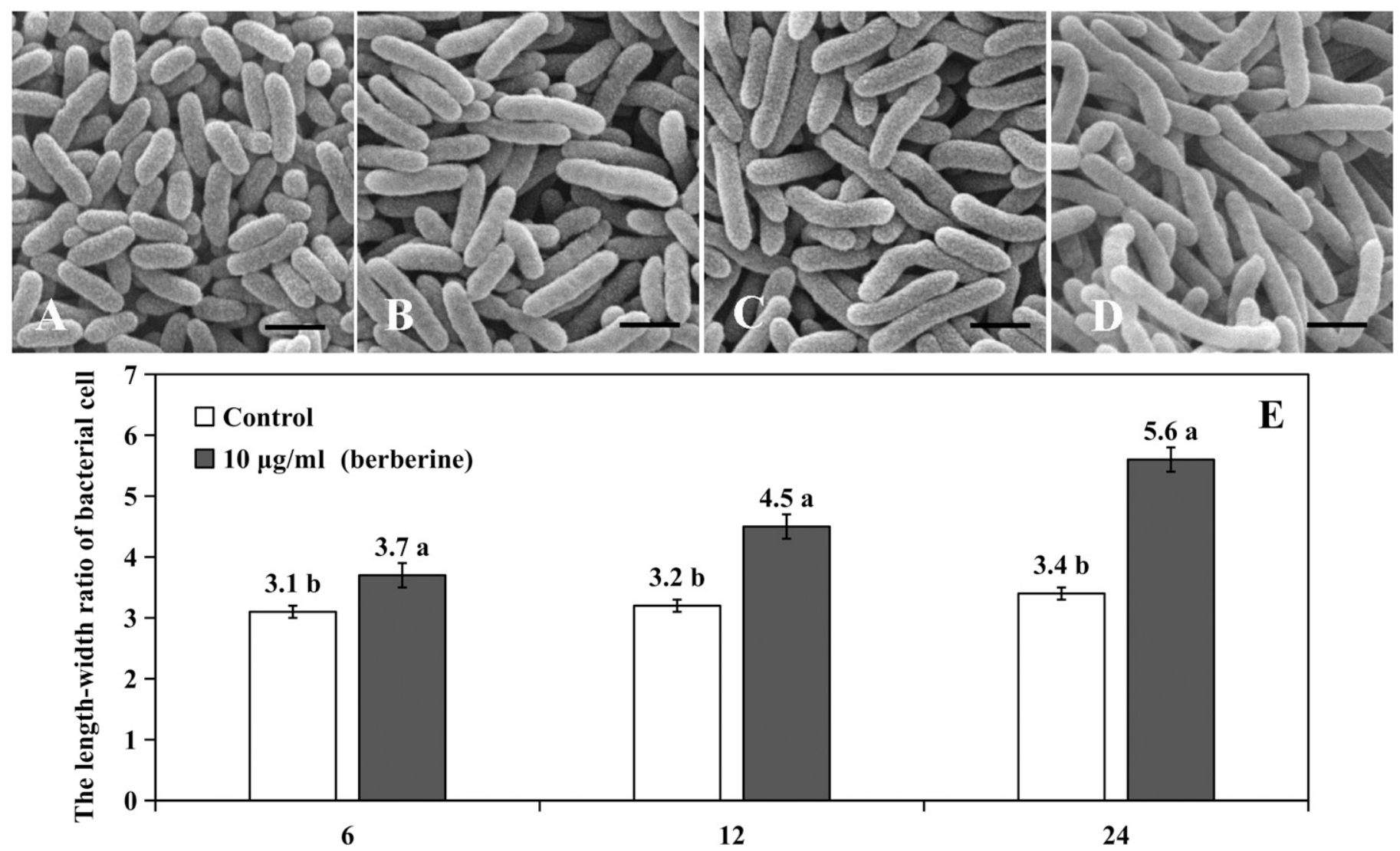

Time of treatment $(\mathrm{h})$

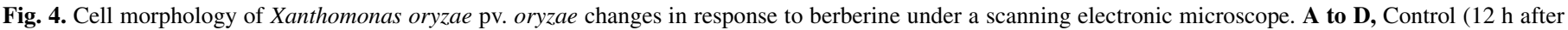

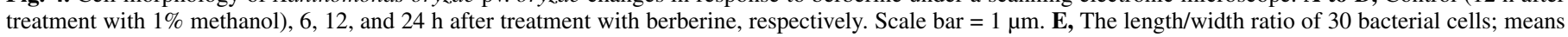

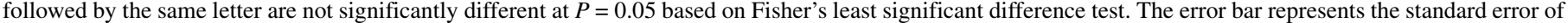
mean. 


\section{DISCUSSION}

Effects of berberine on the virulence of $X$. oryzae pv. oryzae. Biofilm formation and EPS secretion by pathogenic bacteria are associated with the virulence of the bacteria in the host (Sahu et al. 2018). In agreement with the results of the present study, Singh et al. (2017) found that Thymus vulgaris plant oil significantly reduced the biofilm formation of $X$. oryzae pv. oryzae, which was

TABLE 5. Effects of berberine of $\beta$-galactosidase activity in the culture supernatant of Xanthomonas oryzae pv. oryzae ${ }^{\mathrm{y}}$

\begin{tabular}{lc}
\hline $\begin{array}{l}\text { Berberine } \\
\text { concentration }(\mu \mathrm{g} / \mathrm{ml})\end{array}$ & $\mathrm{OD}_{420}( \pm \mathrm{SE})^{\mathrm{z}}$ \\
\hline 0 & $0.028 \pm 0.0078 \mathrm{~d}$ \\
0.625 & $0.029 \pm 0.0023 \mathrm{~d}$ \\
1.25 & $0.046 \pm 0.0020 \mathrm{c}$ \\
2.5 & $0.048 \pm 0.0031 \mathrm{c}$ \\
5 & $0.070 \pm 0.0055 \mathrm{~b}$ \\
10 & $0.110 \pm 0.0023 \mathrm{a}$ \\
\hline
\end{tabular}

$\mathrm{y}$ The optical density at $420 \mathrm{~nm}\left(\mathrm{OD}_{420}\right)$ of the supernatant reflects the activity of $\beta$-galactosidase in bacterial culture medium treated with berberine at different concentrations for $2 \mathrm{~h}$.

${ }^{z}$ Each value is the mean and standard error (SE) of three separate determinations. Means within columns followed by the same letter are not significantly different $(P=0.05)$ according to Fisher's least significant difference test.

TABLE 6. Effect of berberine on respiration metabolism of Xanthomonas oryzae pv. oryzae ${ }^{\mathrm{z}}$

\begin{tabular}{lccc}
\hline & & $\begin{array}{c}\text { Malate } \\
\text { dehydrogenase } \\
\text { activity }(\mathrm{U} / \mathrm{g} \\
\text { protein })( \pm \mathrm{SE})\end{array}$ & $\begin{array}{c}\text { Adenosine } \\
\text { triphosphate } \\
\text { content }(\mu \mathrm{mol} / \mathrm{g} \\
\text { protein })( \pm \mathrm{SE})\end{array}$ \\
\hline Treatments & $\begin{array}{c}\text { Pyruvate content } \\
(\mu \mathrm{mol} / \mathrm{ml})( \pm \mathrm{SE})\end{array}$ & $2.92 \pm 0.22 \mathrm{a}$ & $130.23 \pm 9.76 \mathrm{~b}$ \\
$\begin{array}{c}\text { Control } \\
1.64 \mu \mathrm{g} / \mathrm{ml} \\
(\mathrm{berberine})\end{array}$ & $0.13 \pm 0.004 \mathrm{c}$ & $1.73 \pm 0.25 \mathrm{~b}$ & $222.48 \pm 17.90 \mathrm{~b}$ \\
$\begin{array}{c}5 \mu \mathrm{\mu g} / \mathrm{ml} \\
(\mathrm{berberine})\end{array}$ & $0.32 \pm 0.009 \mathrm{~b}$ & $1.42 \pm 0.32 \mathrm{~b}$ & $377.87 \pm 56.87 \mathrm{a}$ \\
$\begin{array}{c}10 \mu \mathrm{g} / \mathrm{ml} \\
\text { (berberine) }\end{array}$ & $0.89 \pm 0.070 \mathrm{a}$ & $1.36 \pm 0.17 \mathrm{~b}$ & $411.78 \pm 61.14 \mathrm{a}$ \\
\hline
\end{tabular}

${ }^{\mathrm{z}}$ Each value is the mean and standard error (SE) of three separate determinations. Means within columns followed by the same letter are not significantly different $(P=0.05)$ according to Fisher's least significant difference test.

TABLE 7. Levels of cyclic adenosine monophosphate (cAMP) in rice leaves inoculated with Xanthomonas oryzae pv. oryzae strains expressing effector:: cyaA fusion genes ${ }^{\mathrm{x}}$

\begin{tabular}{llc}
\hline Treatments & $\begin{array}{c}\text { Bacterial strains of } \\
\text { X. oryzae pv. oryzae }\end{array}$ & $\begin{array}{c}\text { cAMP } \\
(\mathrm{nmol} / \mathrm{mg} \\
\text { protein })( \pm \mathrm{SE})^{\mathrm{z}}\end{array}$ \\
\hline Treated with $1 \%$ methanol & RS021310-pJAA & $46.30 \pm 1.31 \mathrm{a}$ \\
solution as a control & pJAA & $0.16 \pm 0.02 \mathrm{c}$ \\
$(0 \mu \mathrm{g} / \mathrm{ml}$ berberine $)$ & GX13 & $0.10 \pm 0.03 \mathrm{c}$ \\
Treated with $10 \mu \mathrm{g} / \mathrm{ml}$ & RS021310-pJAA & $2.24 \pm 0.26 \mathrm{~b}$ \\
berberine & pJAA & $0.09 \pm 0.02 \mathrm{c}$ \\
& GX13 & $0.13 \pm 0.04 \mathrm{c}$ \\
\hline
\end{tabular}

$\overline{\mathrm{x}}$ Bacterial strains were treated with berberine $(10 \mu \mathrm{g} / \mathrm{ml})$ and cultured for 12 $\mathrm{h}$, and a $1 \%$ methanol solution was used as a control. Strains were made into solution with distilled water to $10^{8} \mathrm{CFU} / \mathrm{ml}$ and inoculated into rice leaves. The level of cAMP in the inoculated leaves was assayed 3 days after inoculation. Similar results were obtained in three independent experiments.

y The wild-type strain (X. oryzae pv. oryzae GX13) was transformed with effector::cyaA fusion genes (X. oryzae pv. oryzae RS021310-pJAA) or empty vector pJAA ( $X$. oryzae pv. oryzae pJAA).

${ }^{\mathrm{z}}$ Means followed by the same letter are not significantly different $(P=0.01)$ according to Fisher's least significant difference test. consistent with the reduced EPS secretion and reduced virulence of the pathogen (Singh et al. 2017). The $\mathrm{CSH}$ reflects the biofilm formation of bacteria; a marked decrease in the $\mathrm{CSH}$ could represent a disadvantage for the formation of new biofilms by dispersing bacterial cells (Bujdáková et al. 2013). The genes gumB and gumC are both involved in the translocation of EPS across the bacterial membrane in $X$. oryzae pv. oryzae, and EPS production is an important determinant of biofilm formation and an inhibitor of motility (Kim et al. 2009). Therefore, the inhibitory effect of berberine on the formation biofilm of X. oryzae pv. oryzae GX13 may be because of its influence on CSH, the production of EPS, the pathogen population in xylem of rice, and the expression of gumB and gumC, resulting in a decline in virulence of the pathogen.

Bacteria use the sophisticated T2SS to translocate a wide range of proteins, including extracellular hydrolase, from the periplasm across the outer membrane. In the T2SS, the outer membrane secretin GspD forms a multimeric pore for translocation of secreted proteins (Korotkov et al. 2011), and the inner membrane proteins GspE and GspF are used as a scaffold for the assembly of other components (Béatrice et al. 2001). Mutations in genes encoding structural proteins such as GspD and GspE destroy the T2SS, affect the secretion of extracellular enzymes such as cellulase, amylase, and protease, and lead to a decrease in the virulence of $X$. oryzae $\mathrm{pv}$. oryzae (Sun et al. 2005). This study found that in X. oryzae pv. oryzae GX13 treated with berberine, the activity of extracellular hydrolase decreased, and the expressions of $g s p D, g s p E$, and $g s p F$ were downregulated, indicating that the decreased virulence of $X$. oryzae pv. oryzae GX13 treated with berberine was also
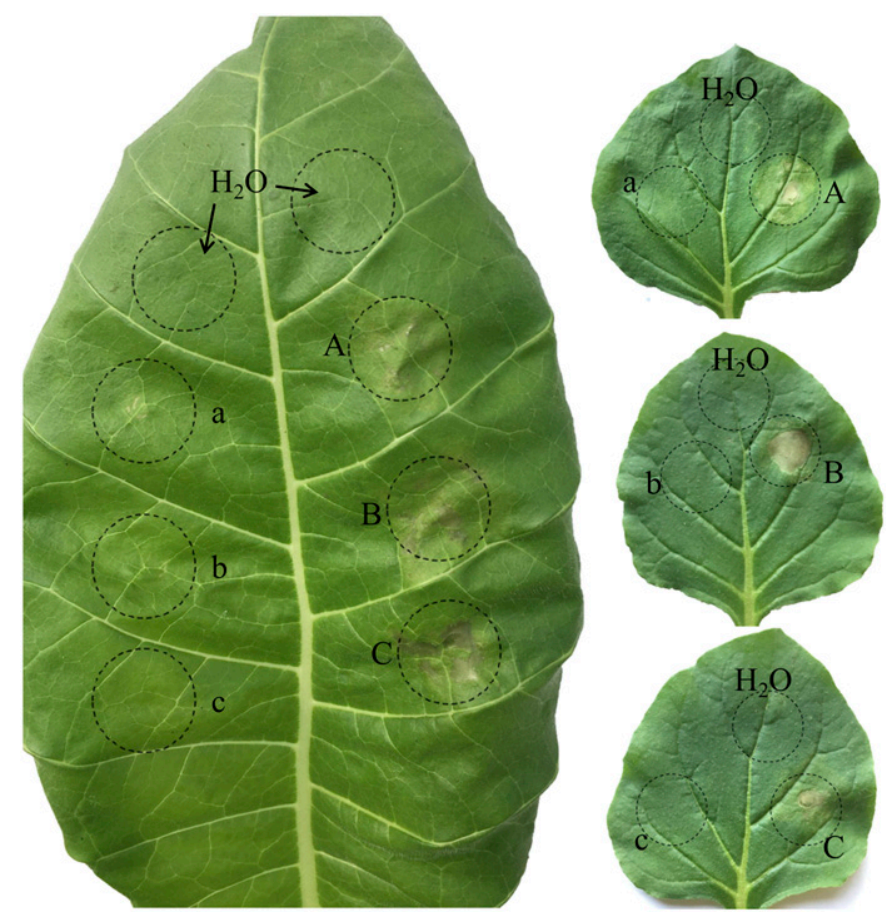

Fig. 6. Xanthomonas oryzae pv. oryzae $\mathrm{GX} 13, X$. oryzae pv. oryzae RS021310-pJAA, and X. oryzae pv. oryzae pJAA strains were inoculated into 4-week-old fully expanded leaves of Nicotiana tabacum (left) and Nicotiana benthamiana (right) at a concentration of $10^{8} \mathrm{CFU} / \mathrm{ml} . A, B$, and $C$ indicate inoculation with the $X$. oryzae pv. oryzae $\mathrm{GX13}, X$. oryzae pv. oryzae RS021310-pJAA, and $X$. oryzae pv. oryzae pJAA strains, respectively, after treatment with $1 \%$ methanol and cultured for $12 \mathrm{~h} ; a, b$, and $c$ were inoculated with the $X$. oryzae pv. oryzae GX13, X. oryzae pv. oryzae RS021310-pJAA, and $X$. oryzae pv. oryzae pJAA strains, respectively, treated with berberine (10 $\mu \mathrm{g} / \mathrm{ml}$ ), and cultured for $12 \mathrm{~h} ; \mathrm{H}_{2} \mathrm{O}$ indicates inoculation with $\mathrm{H}_{2} \mathrm{O}$. The induction of the hypersensitive response was observed and photographed after 3 days after inoculation. 
associated with the effect of berberine on the secretion of cellulase, amylase, and protease by the T2SS.

The T3SS of $X$. oryzae pv. oryzae, encoded by the hrp genes, including $h r c C$, $h r c J$, and $h r c Q$, is an essential determinant of bacterial pathogenicity, which is achieved by controlling the secretion and translocation of effector proteins that cause disease in susceptible hosts (Zhang et al. 2013b). The HrcC protein, encoded by the $h r c C$ gene, is an outer membrane protein that constitutes the T3SS. The HrcJ protein, encoded by the $h r c J$ gene, is a linker protein between the inner and outer membranes of the pathogenic cells and is involved in T3SS formation. Knockout of the gene $h r c J$ in Xanthomonas resulted in a loss of pathogenicity in rice (Zhao et al. 2010). The HrcN protein, a putative ATPase encoded by the $h r c N$ gene, probably activates the T3SS (Lorenz and Büttner 2009). The HrcQ protein, encoded by the $h r c Q$ gene in $X$. oryzae pv. oryzae, is the core component of the T3SS, aiding the secretion of Hpa1 and HrpB2 through the T3SS, leading to hypersensitivity in tobacco and pathogenicity in rice (Zhang et al. $2013 \mathrm{~b}$ ). In this study, berberine affected the expression of $h r p$ genes, and an adenylate cyclase fusion assay demonstrated that berberine affected T3E secretion via the T3SS and reduced the effector translocation of $X$. oryzae pv. oryzae GX13. Protein secretion and translocation into eukaryotic host cells are key processes in the virulence of pathogenic bacteria. The T3SS is a representative apparatus that secretes and translocates virulence proteins out of bacterial cells. Therefore, berberine effectively suppressed the function of the T3SS of X. oryzae pv. oryzae GX13, which may play an important role in decreasing the virulence of $X$. oryzae pv. oryzae GX13.

This study also found that in the two-component systems, the genes $\operatorname{raxH} 2$ and $\operatorname{raxR} 2$, which are associated with the PhoPQ twocomponent regulatory system, and the gene $r p f F$, which encodes the DSF synthase, were upregulated, but the gene $c l p$, which encodes the cAMP receptor-like protein CLP, was downregulated. The PhoPQ two-component regulatory system is needed for AvrXA21 activity, $h r p G$ expression, and virulence in X. oryzae pv. oryzae (Lee et al. 2008), but the mechanism underlying the effect of the upregulated expression of $\operatorname{raxH} 2$ and $\operatorname{raxR} 2$ on the T3SS and virulence in $X$. oryzae pv. oryzae is not clear and warrants further research. DSFs are crucial for successful colonization and virulence of Xanthomonas in host plants; overexpression of rpfF in $X$. hortorum pv. pelargonii led to a significant reduction in the incidence and severity of the disease in pelargonium (Barel et al. 2015). The cAMP receptor-like protein CLP is likely to be the longsought c-di-GMP receptor proteins in the DSF-mediated pathways. CLP is found to be released from DNA binding when incubated with c-di-GMP in competition electrophoretic mobility shift assay and surface plasmon resonance assay, indicating that c-di-GMP acts as a negative regulator for downstream pathogenic gene expression via changing CLP conformation (Chin et al. 2010). The effect of berberine on the virulence of $X$. oryzae pv. oryzae GX13 may be associated with the differential expression of genes involved with the DSF-mediated pathways; for this, a competition electrophoretic mobility shift assay is needed to determine whether CLP is to be released from DNA binding when incubated with c-di-GMP and berberine.

Effect of berberine on cell division and cell structure of $X$. oryzae pv. oryzae. In this study, the $X$. oryzae pv. oryzae GX13 treated with berberine showed cell elongation compared with the wild strains. Bacteria also exhibit this phenomenon after exposure to certain drugs, which can be interpreted as the bacterial SOS reaction (Bai et al. 2010). It has been reported that the Z-ring (FtsQ, FtsA) and Z-ring-associated proteins (ZapE, ZapA) are all essential for cell division (Buddelmeijer and Beckwith 2004; Galli and Gerdes 2010), X. oryzae pv. oryzae has shown reduction in cell division, and seven genes (e.g., zapE, zapA, ftsQ) were downregulated under melatonin treatment (Chen et al. 2019). An initial DNA-damaging event leads to upregulation of the genes $r e c A$ and
lexA, leading to induction of the SOS gene network (Kubiak et al. 2017). Therefore, upregulation of recA and lexA and downregulation of zapE, zapA, fts $Q$, and $f t s A$ may lead to cell elongation in X. oryzae pv. oryzae GX13 under berberine treatment, but an SOS staining test or mutation study of the recA or lexA genes is needed.

This study found that berberine could damage the cell membrane and affected the expression of the genes lpxH, lpxK, $k d t A, f a b B$, and $f a b G$ in $X$. oryzae pv. oryzae GX13. Lipopolysaccharides and fatty acids are important components of cell membranes. LpxH (encoded by $l p x H$ ) is a pyrophosphatase that is involved in LPS synthesis, and previous structures revealed that $\mathrm{LpxH}$ has a helical cap that binds to lipid substrates (Bohl et al. 2018). Tetraacyldisaccharide-1phosphate $4^{\prime}$-kinase, encoded by the lpxK gene, is essential for growth and lipid A biosynthesis per se in bacteria (Wei et al. 2017). 3-deoxy-D-manno-octulosonic-acid (Kdo) transferase, encoded by $k d t A$, is essential for Kdo biosynthesis and cell growth in E. coli (Belunis et al. 1995). Lipid A and Kdo are components of lipopolysaccharides of Xanthomonas (Mohan and Mahadevan. 2001). Downregulation of the genes $l p x K$ and $k d t A$ can decrease the expression of lipid A and Kdo and may affect biosynthesis of the cell membrane and growth in $X$. oryzae pv. oryzae. In addition, fabB and $f a b G$ are involved in fatty acid biosynthesis (von WettsteinKnowles et al. 2006). Differential expression of these genes may damage the function of cell membranes, leading to changes in cell membrane permeability. The cell membranes may be suitable targets for berberine-mediated inhibition of $X$. oryzae $\mathrm{pv}$. oryzae GX13.

Effect of berberine on the energy metabolism of $X$. oryzae pv. oryzae. It is well known that pyruvate is a key intermediate product in the process of biological metabolism, which links the Embden-Meyerhof-Parnas pathway and TCA cycle. In this study, the pyruvate content increased, and the genes $\operatorname{lpd} A, p d h \alpha$, and $p d h \beta$ were downregulated in $X$. oryzae pv. oryzae GX13 under berberine treatment, similar to the response of Metarhizium robertsii upon exposure to heat (Zhang et al. 2018). Studies have shown that knockout of the $l p d A$ gene of $E$. coli can not only "intercept" pyruvate into the TCA cycle but also regulate the synthesis of byproducts such as ethanol and lactic acid at the NADH level, which is beneficial to pyruvate accumulation (Li et al. 2006). The pyruvate dehydrogenase multienzyme complex performs oxidative decarboxylation of pyruvate to acetyl-CoA and is central to the carbon metabolism that links glycolysis to the TCA cycle (Quail et al. 1994). The pyruvate dehydrogenase E1 component catalyzes the decarboxylation of pyruvate to produce $\alpha$-hydroxyethylthiamine-PP, which is a rate-limiting step during the pyruvate dehydrogenase multienzyme complex catalytic cascade. Downregulation of the gene encoding pyruvate dehydrogenase may lead to pyruvate accumulation in $X$. oryzae pv. oryzae GX13. We hypothesized that berberine may affect the energy metabolism and carbon metabolism of $X$. oryzae pv. oryzae GX13 by downregulating the genes $l p d A, p d h \alpha$, and $p d h \beta$.

ATP production in microorganisms can be divided into two modes: substrate-level phosphorylation and oxidative phosphorylation. In this study, the activity of $\mathrm{MDH}$ in $X$. oryzae pv. oryzae GX13 decreased significantly, and its ATP content increased under berberine treatment. Meanwhile, the gene $m d h$ encoding malate dehydrogenase, the gene pyk encoding pyruvate kinase, and the gene $p g k$ encoding phosphoglycerate kinase were downregulated in $X$. oryzae pv. oryzae GX13 treated with berberine. Pyruvate kinase and phosphoglycerate kinase are associated with substrate-level phosphorylation. MDH is an important enzyme in energy metabolism and the TCA cycle in bacteria (Farahani et al. 2016). This finding indicated that berberine can affect energy metabolism by inhibiting substrate-level phosphorylation. However, the NADH dehydrogenase complex-encoding genes пиоA, пиов, and пион were upregulated, and the ATP synthase-encoding genes atpF, $a t p C$, and $a t p B$, which are associated with oxidative phosphorylation, were upregulated in $X$. oryzae pv. oryzae treated with 
berberine. NADH dehydrogenase is an important component of the electron transport pathway. ATP synthase participates in oxidative phosphorylation and synthesizes ATP via a mechanism that is driven by the transmembrane proton motive force. The upregulated expression of these genes in $X$. oryzae pv. oryzae GX13 indicates that ATP production by oxidative phosphorylation is enhanced upon inhibition of substrate-level phosphorylation to meet the energy needs of the pathogen for the repair of damaged cell tissues or initiation of physiological and biochemical reactions against berberine. It is speculated that berberine may inhibit growth by interfering with the energy metabolism of $X$. oryzae pv. oryzae GX13.

Effect of berberine on the chemotaxis of $X$. oryzae $\mathrm{pv}$. oryzae. Bacterial chemotaxis is the motility-based response of some bacteria to a concentration gradient of a chemical attractant or repellant. Chemotactic ligands are detected by cell surface chemoreceptor MCPs; upon binding to a chemotactic ligand, MCPs generate chemotactic signals that are communicated to the flagellar motor via a series of chemotaxis proteins (Kato et al. 2008). In this study, the genes encoding MCPs were upregulated in X. oryzae pv. oryzae GX13 under berberine treatment, indicating that berberine may act as a trigger for flagella-driven chemotaxis to enable $X$. oryzae pv. oryzae GX13 to avoid chemical hazards, and a chemotaxis assay of pathogens to berberine in vitro should be conducted.

In summary, the antibacterial activity of berberine against $X$. oryzae pv. oryzae could occur via inhibition of bacterial growth by alteration of bacterial energy metabolism, respiration, and destruction of the cell membrane. Moreover, berberine also reduced the virulence of $X$. oryzae pv. oryzae and was potentially associated with reduced biofilm formation and extracellular hydrolase activity and suppressed the function of the T3SS of $X$. oryzae pv. oryzae GX13. Finally, the upregulated expression of genes associated with the chemotaxis family might be related to the mechanism of bacterial resistance to berberine. However, mutational studies or further enzymatic experiments should be conducted to definitively support the hypothesis that the berberine is chemically interacting with the targets highlighted in the transcriptome analysis. The results of this study provide a theoretical basis for future experiments to elucidate the molecular targets of berberine in $X$. oryzae pv. oryzae and for further application of berberine for the control of BLB in rice.

\section{ACKNOWLEDGMENTS}

We thank professor Jiang Bo-Le for the E. coli strain containing a plasmid pJAA and the staffs of Beijing Novogene Bioinformation Technology Co., Ltd. for Illumina sequencing of RNA samples.

\section{LITERATURE CITED}

Bai, H., Su, W. Z., Zhu, X. L., Hu, M., and Liu, Y. Q. 2010. Effect of enrofloxacin on gene expression profiles of Escherichia coli. Ann. Microbiol. 60:653-660.

Barel, V., Chalupowicz, L., Barash, I., Sharabani, G., Reuven, M., Dror, O., Burdman, S., and Manulis-Sasson, S. 2015. Virulence and in planta movement of Xanthomonas hortorum pv. pelargonii are affected by the diffusible signal factor (DSF)-dependent quorum sensing system. Mol. Plant Pathol. 16:710-723.

Béatrice, P., Loiseau, L., and Barras, F. 2001. An inner membrane platform in the type II secretion machinery of gram-negative bacteria. EMBO Rep. 2: 244-248.

Belunis, C. J., Clementz, T., Carty, S. M., and Raetz, C. R. H. 1995. Inhibition of lipopolysaccharide biosynthesis and cell growth following inactivation of the kdtA gene in Escherichia coli. J. Biol. Chem. 270:27646-27652.

Blanco, M. T., Sacristan, B., Lucio, L., Blanco, J., Perez-Giraldo, C., and Gomez-Garcia, A. C. 2010. Cell surface hydrophobicity as an indicator of other virulence factors in Candida albicans. Rev. Iberoam. Micol. 27: 195-199.

Bohl, T. E., Ieong, P., Lee, J. K., Lee, T., Kankanala, J., Shi, K., Demir, O., Kurahashi, K., Amaro, R. E., Wang, Z., and Aihara, H. 2018. The substrate- binding cap of the UDP-diacylglucosamine pyrophosphatase $\mathrm{LpxH}$ is highly flexible, enabling facile substrate binding and product release. J. Biol. Chem. 293:7969-7981.

Buddelmeijer, N., and Beckwith, J. 2004. A complex of the Escherichia coli cell division proteins FtsL, FtsB and FtsQ forms independently of its localization to the septal region. Mol. Microbiol. 52:1315-1327.

Bujdáková, H., Didiášová, M., Drahovská, H., and Černáková, L. 2013. Role of cell surface hydrophobicity in Candida albicans biofilm. Cent. Eur. J. Biol. $8: 259-262$

Chen, C. Y., Yang, W., Gan, Y. L., Jiang, G. F., Yang, L. C., Yang, L. Y., and Jiang, B. L. 2014. Construction of a reporter plasmid to identify the secretion and translocation of the type III effectors in Xanthomonas campestris pv. campestris. Acta Phytopathol. Sin. 44:232-238.

Chen, X., Sun, C., Laborda, P., He, Y., Zhao, Y. C., Li, Z. H., and Liu, F. Q. 2019. Melatonin treatments reduce the pathogenicity and inhibit the growth of Xanthomonas oryzae pv. oryzicola. Plant Pathol. 68:288-296.

Chen, X. L., Zhang, Z., Lin, S. P., Zhou, X. J., and Dong, A. B. 2012. Control efficacy test of $0.5 \%$ berberine aqueous solution on tomato gray mold. Shanghai Veget. 4:68-69.

Chen, Y., Yang, X., Zhang, A. F., Zhang, Y., Wang, W. X., Gao, T. C., Yao, J., and Yuan, S. K. 2015. Activity of a novel bactericide, zinc thiazole against Xanthomonas oryzae, pv. oryzae, in Anhui Province of China. Ann. Appl. Biol. 166:129-135.

Chin, K. H., Lee, Y. C., Tu, Z. L., Chen, C. H., Tseng, Y. H., Yang, J. M., Ryan, R. P., McCarthy, Y., Dow, J. M., Wang, A. H. J., and Chou, S. H. 2010. The cAMP receptor-like protein CLP is a novel c-di-GMP receptor linking cell-cell signaling to virulence gene expression in Xanthomonas campestris. J. Mol. Biol. 396:646-662.

Fan, W. W., Yuan, G. Q., Li, Q. Q., and Lin, W. 2014. Antibacterial mechanisms of methyl gallate against Ralstonia solanacearum. Australas. Plant Pathol. 43:1-7.

Farahani, A. S., Taghavi, S. M., and Afsharifar, A. 2016. Induction of superoxide dismutase, malate dehydrogenase and phenylalanine ammonialyase during enhancing resistance of common bean against Xanthomonas axonopodis pv. phaseoli by exogenous salicylic acid. J. Plant Dis. Prot. 123: 83-87.

Fu, W., Tian, G., Pei, Q., Ge, X., and Tian, P. F. 2017. Evaluation of berberine as a natural compound to inhibit peach brown rot pathogen monilinia fructicola. Crop Prot. 91:20-26.

Furutani, A. 2009. Identification of novel type III secretion effectors in Xanthomonas oryzae pv. oryzae. Mol. Plant-Microbe Interact. 22:96-106.

Galli, E., and Gerdes, K. 2010. Spatial resolution of two bacterial cell division proteins: ZapA recruits ZapB to the inner face of the Z-ring. Mol. Microbiol. 76:1514-1526.

Genevaux, P., Muller, S., and Bauda, P. 1996. A rapid screening procedure to identify mini-Tn 10 insertion mutants of Escherichia coli $\mathrm{K}-12$ with altered adhesion properties. FEMS Microbiol. Lett. 142:27-30.

Huang, Y. Z., Wang, K. Y., Gu, C. X., Yu, G. X., Zhao, Y., Liu, S. M., Nie, Y. Q., and Yang, H. 2018. Berberine, a natural plant alkaloid, synergistically sensitizes human liver cancer cells to sorafenib. Oncol. Rep. 40: 1525-1532.

Jin, J. L., Hua, G. Q., Zhen, M., and Gao, P. J. 2011. Antibacterial mechanisms of berberine and reasons for little resistance of bacteria. Chin. Herb. Med. 03:27-35.

Kang, S., Li, Z. W., Yin, Z. Q., Jia, R. Y., Song, X., Li, L., Chen, Z. Z., Peng, L. C., Qu, J., Hu, Z. Q., Lai, X., Wang, G. X., Liang, X. X., He, C. L., and Yin, L. Z. 2015. The antibacterial mechanism of berberine against Actinobacillus pleuropneumoniae. Nat. Prod. Res. 29:2203-2206.

Kato, J., Kim, H. E., Takiguchi, N., Kuroda, A., and Ohtake, H. 2008. Pseudomonas aeruginosa as a model microorganism for investigation of chemotactic behaviors in ecosystem. J. Biosci. Bioeng. 106:1-7.

Kim, S. Y., Kim, J. G., Lee, B. M., and Cho, J. Y. 2009. Mutational analysis of the gum gene cluster required for xanthan biosynthesis in Xanthomonas oryzae pv. oryzae. Biotechnol. Lett. 31:265-270.

Korotkov, K. V., Johnson, T. L., Jobling, M. G., Pruneda, J., Pardon, E., Héroux, A., Turley, S., Steyaert, J., Holmes, R. K., Sandkvist, M., and Hol, W. G. J. 2011. Structural and functional studies on the interaction of GspC and GspD in the type II secretion system. PLoS Pathog 7:e1002228.

Kubiak, J. M., Culyba, M. J., Liu, M. Y., Mo, C. Y., Goulian, M., and Kohli, R. M. 2017. A small-molecule inducible synthetic circuit for control of the SOS gene network without DNA damage. ACS Synth. Biol. 6:2067-2076.

Kumariya, R., Sood, S. K., Rajput, Y. S., and Garsa, A. K. 2015. Gradual pediocin PA-1 resistance in Enterococcus faecalis confers cross-protection to diverse pore-forming cationic antimicrobial peptides displaying changes in cell wall and mannose PTS expression. Ann. Microbiol. 65:721-732.

Laha, G. S., and Muralidharan, D. K. 2008. Population dynamics of Xanthomonas oryzae pv. oryzae in rice leaves. J. Mycol. Plant Pathol. 38:112-115.

Lee, S. W., Jeong, K. S., Han, S. W., Lee, S. E., Phee, B. K., Hahn, T. R., and Ronald, P. 2008. The Xanthomonas oryzae pv. oryzae PhoPQ two-component 
system is required for AvrXA21 activity, hrpG expression, and virulence. J. Bacteriol. 190:2183-2197.

Li, M., Ho, P. Y., Yao, S., and Shimizu, K. 2006. Effect of lpdA gene knockout on the metabolism in Escherichia coli based on enzyme activities, intracellular metabolite concentrations and metabolic flux analysis by $13 \mathrm{C}$ labeling experiments. J. Biotechnol. 122:254-266.

Liang, X. Y., Yu, X. Y., Dong, W. X., Guo, S. J., Xu, S., Wang, J. X., and Zhou, M. G. 2015. Two thiadiazole compounds promote rice defence against Xanthomonas oryzae pv. oryzae by suppressing the bacterium's production of extracellular polysaccharides. Mol. Plant Pathol. 16:882-892.

Liang, X. Y., Yu, X. Y., Pan, X. Y., Wu, J., Duan, Y. B., Wang, J. X., and Zhou, M. G. 2016. A thiadiazole reduces the virulence of Xanthomonas oryzae pv. oryzae by inhibiting the histidine utilization pathway and quorum sensing. Mol. Plant Pathol. 19:116-128.

Lorenz, C., and Büttner, D. 2009. Functional characterization of the type III secretion ATPase HrcN from the plant pathogen Xanthomonas campestris pv. vesicatoria. J. Bacteriol. 191:1414-1428.

Mohan, N., and Mahadevan, A. 2001. Effect of phenol on lipid and fatty acid profile of Xanthomonas oryzae pv. oryzae. Indian J. Exp. Biol. 39: 1062-1064.

Molina-Santiago, C., Daddaoua, A., Gómez-Lozano, M., Udaondo, Z., Molin, S., and Ramos, J.-L. 2015. Differential transcriptional response to antibiotics by Pseudomonas putida DOT-T1E. Environ. Microbiol. 17: 3251-3262.

Quail, M. A., Haydon, D. J., and Guest, J. R. 1994. The pdhR-aceEF-lpd operon of Escherichia coli expresses the pyruvate dehydrogenase complex. Mol. Microbiol. 12:95-104.

Sack, R. B., and Froehlich, J. L. 1982. Berberine inhibits intestinal secretory response of Vibrio cholerae and Escherichia coli enterotoxins. Infect. Immun. 35:471-475.

Sahu, S. K., Zheng, P., and Yao, N. 2018. Niclosamide blocks rice leaf blight by inhibiting biofilm formation of Xanthomonas oryzae. Front. Plant Sci. 9: 408 .

Sakthivel, K., Gautam, R. K., Manigundan, K., Singh, R., Ramalingam, J., Laha, G. S., Kumar, A., and Velazhahan, R. 2017. The host background of rice influences the resistance expression of a three genes pyramid (xa5+ $x a 13+x a 21$ ) to bacterial blight (Xanthomonas oryzae pv. oryzae) pathotypes of Indian mainland and Bay islands. Plant Breed. 136:357-364.

Singh, A., Gupta, R., Tandon, S., and Pandey, R. 2017. Thyme oil reduces biofilm formation and impairs virulence of Xanthomonas oryzae. Front. Microbiol. 8:1074.

Sory, M. P., Boland, A., Lambermont, I., and Cornelis, G. R. 1995. Identification of the yope and yoph domains required for secretion and internalization into the cytosol of macrophages, using the cyaA gene fusion approach. Proc. Natl. Acad. Sci. 92:11998-12002.

Sun, Q. H., Hu, J., Huang, G. X., Ge, C., Fang, R. X., and He, C. Z. 2005. Type-II secretion pathway structural gene xpsE, xylanase and cellulase secretion and virulence in Xanthomonas oryzae pv. oryzae. Plant Pathol. 54: $15-21$.

von Wettstein-Knowles, P., Olsen, J. G., Mcguire, K. A., and Henriksen, A. 2006. Fatty acid synthesis. Role of active site histidines and lysine in CysHis-His-type beta-ketoacyl-acyl carrier protein synthases. FEBS J. 273: 695-710.

Wang, C., Gong, B., Bushel, P. R., Thierry-Mieg, J., Thierry-Mieg, D., Xu, J., Fang, H., Hong, H., Shen, J., Su, Z., Meehan, J., Li, X., Yang, L., Li, H., Łabaj, P. P., Kreil, D. P., Megherbi, D., Gaj, S., Caiment, F., van Delft, J., Kleinjans, J., Scherer, A., Devanarayan, V., Wang, J., Yang, Y., Qian, H. R., Lancashire, L. J., Bessarabova, M., Nikolsky, Y., Furlanello, C., Chierici, M., Albanese, D., Jurman, G., Riccadonna, S., Filosi, M., Visintainer, R., Zhang, K. K., Li, J., Hsieh, J. H., Svoboda, D. L., Fuscoe, J. C., Deng, Y., Shi, L., Paules, R. S., Auerbach, S. S., and Tong, W. 2014. The concordance between RNA-seq and microarray data depends on chemical treatment and transcript abundance. Nat. Biotechnol. 32:926-932.

Wei, J. R., Richie, D. L., Mostafavi, M., Metzger, L. E., Rath, C. M., and Sawyer, W. S. 2017. LpxK is essential for growth of Acinetobacter baumannii ATCC 19606: Relationship to toxic accumulation of lipid A pathway intermediates. MSphere 2:e00199-17.

Woods, G. L., Williams-Bouyer, N., Wallace, R. J., Brown-Elliott, B. A., Witebsky, F. G., and Conville, P. S. 2003. Multisite reproducibility of results obtained by two broth dilution methods for susceptibility testing of $M y$ cobacterium avium complex. J. Clin. Microbiol. 41:627-631.

Yang, B., and Bogdanove, A. 2013. Inoculation and virulence assay for bacterial blight and bacterial leaf streak of rice. Methods Mol. Biol. 956: 249-255.

Yu, J. L., and Yang, W. D. 2005. Plant resources of berberine. Chin. Herb. Med. 36:1434-1436.

Yuan, G. Q., Chen, Y. Y., Li, F. J., Zhou, R. J., Li, Q. Q., Lin, W., and Huang, L. H. 2017. Isolation of an antibacterial substance from Mahonia fortunei and its biological activity against Xanthomonas oryzae pv. oryzicola. J. Phytopathol. 165:289-296.

Zhang, F., Du, Z. L., Huang, L. Y., Cruz, C. V., Zhou, Y. L., and Li, Z. K. 2013a. Comparative transcriptome profiling reveals different expression patterns in Xanthomonas oryzae pv. oryzae strain with putative virulencerelevant genes. PLoS One 8:e64267.

Zhang, X., Leger, R. J. S., and Fang, W. 2018. Stress-induced pyruvate accumulation contributes to cross protection in a fungus. Environ. Microbiol. 20:1158-1169.

Zhang, X. P., Wang, C. L., Zheng, C. K., Che, J. Y., Li, Y. Q., and Zhao, K. J. 2013b. HrcQ is necessary for Xanthomonas oryzae pv. oryzae HR-induction in non-host tobacco and pathogenicity in host rice. Crop J. 1:143-150.

Zhao, W. X., Han, Y. C., Cui, Y. P., Zhao, M. Q., Li, Y. R., Zou, L. F., and Chen, G. Y. 2010. HrcJ is involved in type-III apparatus formation of Xanthomonas oryzae pv. oryzicola for hypersensitive response in non-host tobacco and pathogenicity in rice. Sci. Agric. Sin. 43:72-79. 